\title{
Article \\ A Role for TGF $\beta$ Signaling in Preclinical Osteolytic Estrogen Receptor-Positive Breast Cancer Bone Metastases Progression
}

\author{
Julia N. Cheng ${ }^{1}$, Jennifer B. Frye ${ }^{2}$, Susan A. Whitman ${ }^{2}$, Andrew G. Kunihiro ${ }^{3}$, Ritu Pandey ${ }^{4}$ \\ and Janet L. Funk ${ }^{2,3, *}$ \\ 1 Cancer Biology Graduate Interdisciplinary Program, University of Arizona, Tucson, AZ 85724, USA; \\ juliacheng@email.arizona.edu \\ 2 Department of Medicine, University of Arizona, Tucson, AZ 85724, USA; jabeisch@email.arizona.edu (J.B.F.); \\ susanwhitman@email.arizona.edu (S.A.W.) \\ 3 Department of Nutritional Sciences, University of Arizona, Tucson, AZ 85724, USA; \\ akunihiro@email.arizona.edu \\ 4 Department of Cellular and Molecular Medicine, University of Arizona, Tucson, AZ 85724, USA; \\ ritu@arizona.edu \\ * Correspondence: jfunk@u.arizona.edu; Tel.: +1-(520)-626-3242
}

check for updates

Citation: Cheng, J.N.; Frye, J.B.; Whitman, S.A.; Kunihiro, A.G.; Pandey, R.; Funk, J.L. A Role for TGF $\beta$ Signaling in Preclinical Osteolytic Estrogen Receptor-Positive Breast Cancer Bone Metastases Progression. Int. J. Mol. Sci. 2021, 22, 4463. https://doi.org/10.3390/ ijms22094463

Academic Editor: Ingunn Holen

Received: 20 March 2021

Accepted: 19 April 2021

Published: 24 April 2021

Publisher's Note: MDPI stays neutral with regard to jurisdictional claims in published maps and institutional affiliations.

Copyright: (c) 2021 by the authors. Licensee MDPI, Basel, Switzerland. This article is an open access article distributed under the terms and conditions of the Creative Commons Attribution (CC BY) license (https:// creativecommons.org/licenses/by/ $4.0 /)$.

\begin{abstract}
While tumoral Smad-mediated transforming growth factor $\beta$ (TGF $\beta$ ) signaling drives osteolytic estrogen receptor $\alpha$-negative (ER-) breast cancer bone metastases (BMETs) in preclinical models, its role in ER+ BMETs, representing the majority of clinical BMETs, has not been documented. Experiments were undertaken to examine Smad-mediated TGF $\beta$ signaling in human ER+ cells and bone-tropic behavior following intracardiac inoculation of estrogen $\left(E_{2}\right)$-supplemented female nude mice. While all ER+ tumor cells tested (ZR-75-1, T47D, and MCF-7-derived) expressed TGF $\beta$ receptors II and I, only cells with TGF $\beta$-inducible Smad signaling (MCF-7) formed osteolytic BMETs in vivo. Regulated secretion of PTHrP, an osteolytic factor expressed in $>90 \%$ of clinical BMETs, also tracked with osteolytic potential; TGF $\beta$ and $\mathrm{E}_{2}$ each induced PTHrP in bone-tropic or BMET-derived MCF-7 cells, with the combination yielding additive effects, while in cells not forming BMETs, PTHrP was not induced. In vivo treatment with 1D11, a pan-TGF $\beta$ neutralizing antibody, significantly decreased osteolytic ER+ BMETs in association with a decrease in bone-resorbing osteoclasts at the tumor-bone interface. Thus, TGF $\beta$ may also be a driver of ER+ BMET osteolysis. Moreover, additive pro-osteolytic effects of tumoral $\mathrm{E}_{2}$ and TGF $\beta$ signaling could at least partially explain the greater propensity for ER+ tumors to form BMETs, which are primarily osteolytic.
\end{abstract}

Keywords: breast cancer; bone metastases; estrogen receptor positive; TGF $\beta$; PTHrP

\section{Introduction}

The majority of patients with metastatic breast cancer have bone metastases (BMETs), which are primarily osteolytic and currently lack a cure [1-4]. Most BMETs occur in patients with estrogen receptor-positive (ER+) tumors, both due to the higher prevalence of this tumor subtype, including among those with metastatic disease (70\%), as well as the higher prevalence of BMETs in ER+ (vs. ER-) metastatic disease [5-8]. Despite rates of initial tumor cell dissemination to bone that appear similar regardless of ER status, clinically evident BMETs develop with twice the frequency in ER+ (vs. ER-) metastatic disease and remain concordant for ER+ expression in a majority of cases [9-11]. In contrast, $\mathrm{ER}+$ metastasis formation rates at non-bone sites are less than or equal to those of ERtumors [8]. Therefore, specific modeling of ER+ breast cancer BMET is clinically relevant due to its prevalence, and also due to the possibility that tumoral ER+ signaling could be a mediator, and not just a marker, specific to metastasis progression within the bone microenvironment. Recent experiments conducted by our laboratory support this postulate, providing what is, to the best of our knowledge, the first evidence of a possible causal 
role for tumoral ER signaling in mediating tumor-associated osteolysis in ER+ BMET [12]. In vivo peritumoral osteolysis, osteoclast formation, and osteolytic BMET progression all progressed in an estrogen $\left(E_{2}\right)$ dose-dependent fashion in a human ER+ breast cancer cell (MCF-7) osteolytic BMET model, independent of direct estrogenic effects on the bone milieu or tumor cell proliferation, but in association with ER-mediated tumoral secretion of parathyroid hormone-related protein (PTHrP), an osteolytic factor expressed with greater prevalence in osseus vs. non-osseus metastases [13-18], providing a possible mechanistic basis for the $\mathrm{E}_{2}$-driven tumor-associated osteolysis documented in vivo.

In addition to its common expression in clinical BMET, PTHrP has been a molecule of interest in the pathogenesis of osteolytic breast cancer BMET since being identified as a primary driver of metastatic progression in the first preclinical breast cancer BMET model described over two decades ago, which utilized bone tropic ER- MDA-MB-231 cells, variants of which have remained a mainstay of preclinical BMET research to the present day $[14,15,19,20]$. A large body of evidence now exists, using MDA-MB-231 variants and other ER-cells (e.g., murine 4T1), that identifies tumoral Smad-mediated transforming growth factor $\beta$ (TGF $\beta$ ) signaling as a primary driver of osteolytic BMET progression in ER- BMET models [19,21-23]. TGF $\beta$ released from resorbed bone matrix mediates these effects via binding to tumor cell TGF $\beta$ receptor II (TGF $\beta$ RII), activating canonical Smad2/3 signaling with additional contributions of non-canonical TGF $\beta$ signaling pathways (e.g., mitogen-activated protein kinases [MAPK]), subsequently inducing tumoral expression of pro-metastatic factors [23-26], including PTHrP, the same osteolytic factor induced by $E_{2}$ in the ER+ BMET model. In ER- models, specific blockade of tumoral Smadmediated TGF $\beta$ signaling $[22,24,27,28]$ reduces osteolytic ER- BMET size in combination with a reduction in tumor-associated osteoclasts, thus revealing a key pathogenic role for tumoral TGF $\beta$ signaling in osteolysis. An important but potentially more limited role for TGF $\beta$ signaling in osteoclast precursors in metastatic progression in these same models has been identified $[29,30]$. Untangling the complexities of tumoral vs. bone TGF $\beta$ signaling is difficult. However, therapeutic benefits of TGF $\beta$ neutralization are clear in ER- BMET models, as numerous studies have demonstrated significant reductions in osteolytic ERBMET progression in response to systemic neutralization of TGF $\beta$ signaling [31,32], leading to a proposed use of TGF $\beta$-targeting therapeutics in breast cancer BMETs treatment $[21,33]$.

Still largely unexplored, however, is whether TGF $\beta$, and in particular tumoral TGF $\beta$ signaling, has a role in driving bone metastatic progression for ER+ tumors. This is a relevant question since in vitro evidence in ER+ human breast cancer cells of reciprocal expression of ER $\alpha$ and TGF $\beta$ RII [34-36] and $E_{2}$ inhibition of TGF $\beta$-induced Smad signaling [37-40] suggests that anti-TGF $\beta$ therapeutics could be less effective for the majority of patients with BMETs, i.e., those with ER+ tumors, if tumoral TGF $\beta$ signaling in ER+ cells does not contribute to osteolytic BMET progression. Therefore, studies were undertaken to examine a role for TGF $\beta$ signaling in ER+ osteolytic BMET progression using a variety of in vivo human ER+ osteolytic breast cancer xenograft models, including an assessment of tumoral Smad-mediated TGF $\beta$ signaling and possible crosstalk in bone tropic ER+ breast cancer cells between osteolytic TGF $\beta$ and $\mathrm{E}_{2}$ signaling pathways.

\section{Results}

\subsection{TGF $\beta R$ Expression and TGF $\beta$-Stimulated Smad Signaling in Estrogen Receptor-Positive $(E R+)$ Breast Cancer Cells}

Luminal ER $\alpha$-expressing (ER+) human breast cancer cell lines, MCF-7, T47D, and ZR75-1 (Figure 1A), each expressed TGF $\beta$ receptors II and I (TGF $\beta$ RII and I, Figure 1A) at levels similar to those in bone-tropic MDA-MB-231 breast cancer cells (MDA-SA), an ER-cell line provided by Dr. Theresa Guise that forms TGF $\beta$-dependent BMET in vivo $[22,24,41]$. However, Smad signaling (phosphorylation of Smad2 or Smad 3) was only TGF $\beta$-inducible in MCF-7 cells, and not in T47D or ZR-75-1 cells (Figure 1B). Notably, while Smad2 and Smad4, a required co-factor for pSmad2/3-mediated gene expression (Supplemental Figure S1), were expressed in all ER+ cell lines, the lack of Smad3 phosphorylation in 
T47D and ZR-75-1 cells was associated with markedly lower or undetectable Smad3 levels (Figure 1B).

A.

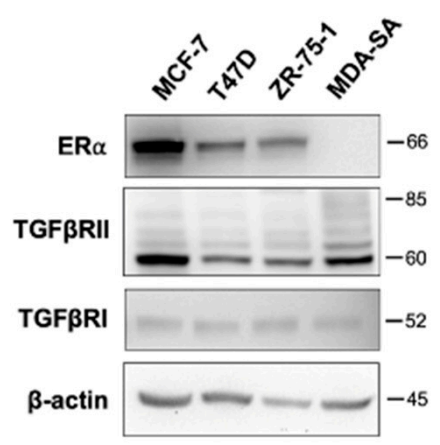

B.

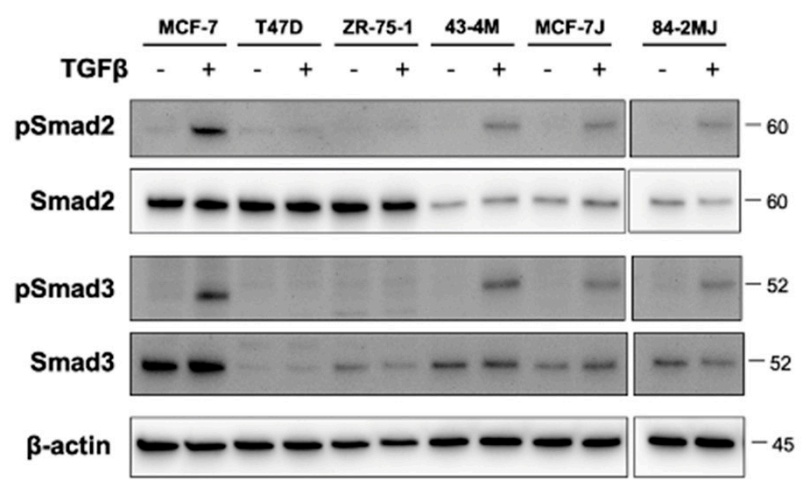

C.

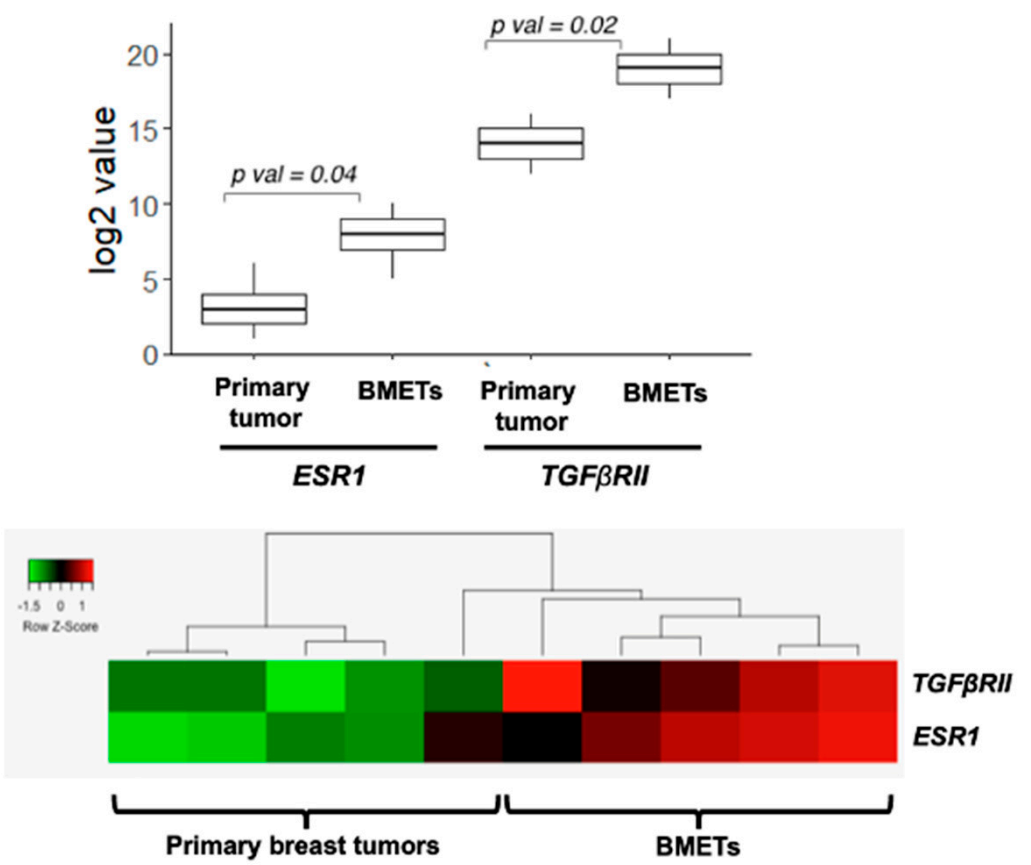

Figure 1. Transforming growth factor $\beta$ (TGF $\beta$ ) receptor expression and TGF $\beta$-inducible Smad signaling in estrogen receptor-positive (ER+) breast cancer cells. (A) Constitutive ER $\alpha$, TGF $\beta$ RII, and TGF $\beta$ RI protein levels in human ER+ MCF-7, T47D, and ZR-75-1 cells as compared with ER- MDA-SA cells, by Western blot analysis; (B) Smad2/3 expression and TGF $\beta$-stimulated ( $5 \mathrm{ng} / \mathrm{mL}$ for $1 \mathrm{~h}$ ) Smad2 and Smad3 phosphorylation in MCF-7, MCF-7J, T47D, ZR-75-1, and bone metastasis (BMET)-derived 43-4M (from MCF-7) and 84-2MJ (from MCF-7J) cells, from a single blot; (C) elevated (top) co-expression (bottom) of ESR1 and TGF $\beta R I I$ genes in human clinical BMETs vs. primary breast tumors from GEO dataset GSE39494 ( $n=5$ /group, unpaired).

Consistent with the findings of ER and TGF $\beta$ RII co-expression in human ER+ breast cancer cell lines, in a clinical breast cancer series, ESR1 and TGF $\beta R I I$ genes were similarly co-expressed in breast cancer primary tumors and BMETs (Figure 1C). Notably, expression levels of both receptors were significantly higher in tumor cells derived from BMETs, as compared with cells in primary tumors from women with BMETs (Figure 1C). 


\subsection{Only ER+Cells with TGF $\beta$-Inducible Smad Signaling Formed Osteolytic Bone Metastases (BMETs) In Vivo}

When MCF-7 cells, MCF-7J (a MCF-7 subline transfected to express luciferase), T47D, or ZR-75-1 cells were inoculated into $\mathrm{E}_{2}$-supplemented female athymic nude mice, using methods previously established [12,41], only ER+ cells with TGF $\beta$-inducible Smad signaling (MCF-7 and MCF-7J, Figure 1B) formed osteolytic BMETs. Osteolytic BMET lesions, confirmed by histology (MCF-7) or BLI (MCF-7J), reached maximal incidence by 3 weeks post tumor inoculation and were still increasing in size by the study's end at 6 weeks (Figure 2A,B). Tumor cells within BMETs retained their luminal-type structure (Figure 2B inset, left) and $E R \alpha$ expression (Figure 2B inset, right, brown), and tumor cells isolated from these ER+ BMETs (43-4M from MCF-7-inoculated and 84-2MJ from MCF-7J-inoculated) retained the characteristics of inoculated cells with regards to TGF $\beta$-inducible Smad signaling, albeit with somewhat reduced levels of Smad expression (Figure 1B); ER, TGF $\beta$ RII, and TGF $\beta$ RI receptor expression (Figure 2C); and epithelial phenotype (expressing E-cadherin, but not vimentin, contrasting with ER- MDA-SA cells, Supplemental Figure S2). Notable was the absence of non-osseous metastases in mice inoculated with MCF-7 or MCF-7J cells, as determined by gross necropsy or bioluminescence.

A.

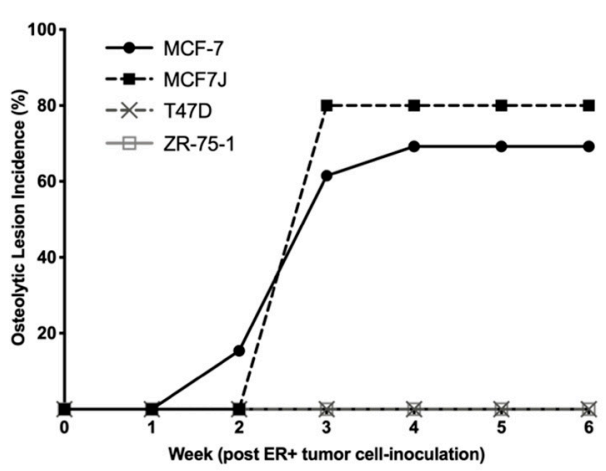

B.

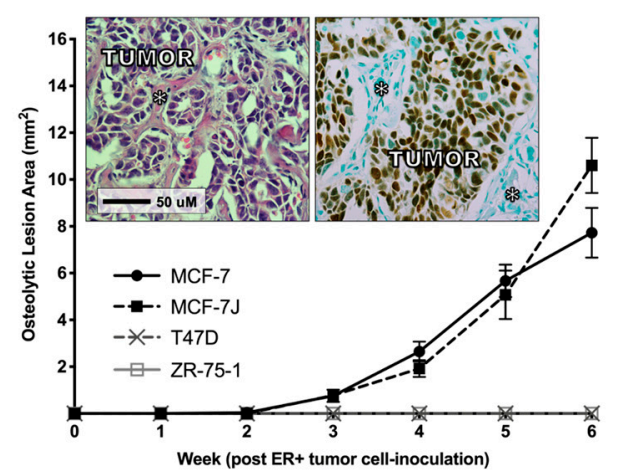

C.

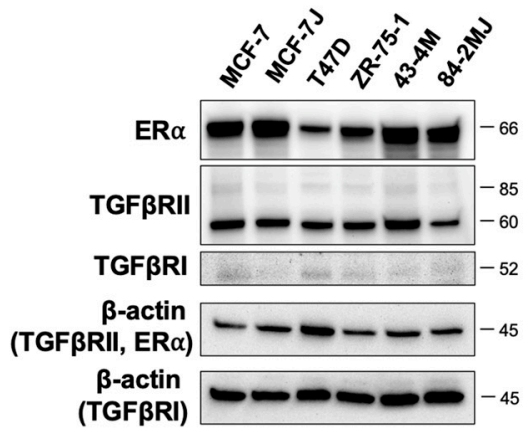

Figure 2. In vivo osteolytic BMET progression of ER+ breast cancer cells inoculated into $\mathrm{E}_{2}$-supplemented mice. (A) Osteolytic BMET lesion incidence and (B) osteolytic lesion area in hind limbs of $E_{2}$-supplemented mice inoculated with ER+ tumor cells as measured by radiographs and confirmed by histology ( $n=5-13$ /group). Mice injected with T47D or ZR-75-1 cells did not form any visibly detectable osteolytic BMET lesions. Inset, representative histological cross-sections of metastases in bone that were H\&E- (left) or ER $\alpha$ immuno-stained (right, brown) demonstrate luminal structure and ER $\alpha$ expression of ER+ MCF-7 BMETs. * , bone. (C) ER $\alpha$, TGF $\beta$ RII, and TGF $\beta$ RI protein expression, as demonstrated by Western blot, in ER+ MCF-7, MCF-7J, T47D, or ZR-75-1 cells as compared with BMET-derived 43-4M (from MCF-7) or 84-2MJ (from MCF-7J) cells. Results are representative of findings in additional MCF-7-BMET-derived cells tested (data not shown).

In contrast to MCF-7 and MCF-7J cells, T47D and ZR-75-1 cells did not form osteolytic BMETs in vivo (Figure 2A,B), nor was there any histological evidence of ER+ tumors in hind limb cross sections (data not shown). Interestingly, however, ER+ human tumor cells could still be isolated and propagated from hind limbs of $E_{2}$-supplemented T47D and ZR75-1-inoculated mice 6 weeks post inoculation, albeit with a lower frequency as compared with mice with MCF-7-derived BMETs (e.g., 33\% of hind limbs from ZR-75-inoculated vs. $74 \%$ from MCF-7-inoculated), suggesting that the complete lack of osteolytic BMET formation in T47D and ZR-75-1-inoculated mice was not due to the absence of tumor cell dissemination to bone. Differences in proliferation rates among the cell lines also could not explain the differential appearance of osteolytic lesions in MCF-7-inoculated mice at 2 weeks vs. complete absence of lesions after 6 weeks (or up to 9 weeks in a small number of mice (data not shown)) in T47D- or ZR-75-1-inoculated mice, since in vitro doubling times for T47D or ZR-75-1 cells in estrogen-replete media were similar to, or only two-fold longer, than MCF-7 cells (48, 54, and 91 h, for MCF-7, T47D, and ZR-75-1, respectively). 


\subsection{Effects of $E_{2}$ and/or TGF $\beta$ on ER $\alpha, T G F \beta R I I$, and Smad Activation in Bone-Tropic ER+Cells}

Due to reports of antagonistic crosstalk between $E_{2}$ and Smad-mediated TGF $\beta$ signaling in breast cancer cells $[34,35,37-40]$ and our previous demonstration of the $E_{2-}$ dependency of osteolysis in ER+ MCF-7 BMETs [12], the time dependent effects of each agent on expression and/or activation of the opposing receptor were assessed in bonetropic ER+ tumor cells. Untreated control cells were included at each time point to account for possible changes in protein levels attributable to the addition of fresh media at the start of the experiment (Figure 3A). TGF $\beta$ stimulation of MCF-7 BMET-derived ER+ 43-4M cells, although tending to reduce $E R \alpha$ levels at the later times, did not prevent $E_{2}$ activation of $\mathrm{ER} \alpha$ (i.e., phosphorylation at S104/106 and S118) at any time (Figure 3A). Furthermore, TGF $\beta$ stimulation alone did not result in ER $\alpha$ phosphorylation (Figure 3A), a putative mechanism by which growth factors can alter ER signaling [42]. $E_{2}$ stimulation did not reduce TGF $\beta$ RII levels (Figure 3B), indeed, at later timepoints, TGF $\beta$ RII levels were slightly increased in $\mathrm{E}_{2}$-treated cells. When assessing $\mathrm{E}_{2}$ effects on TGF $\beta$-induced Smad signaling in MCF-7 (Figure 4A) and MCF-7 BMET-derived 43-4M (Figure 4B) cells, $\mathrm{E}_{2}$ pretreatment downregulated TGF $\beta$-induced Smad activation in both cell lines, an effect that peaked with $5 \mathrm{~h}$ of $\mathrm{E}_{2}$ pretreatment; however, this effect was transient and of much shorter duration in BMET-derived ER+ $43-4 \mathrm{M}$ cells. Thus, neither $\mathrm{E}_{2}$ nor TGF $\beta$ appeared to prevent the expression or activation of the opposing receptor, including TGF $\beta$-mediated Smad signaling, in ER+ cells isolated from osteolytic BMETs.

A.

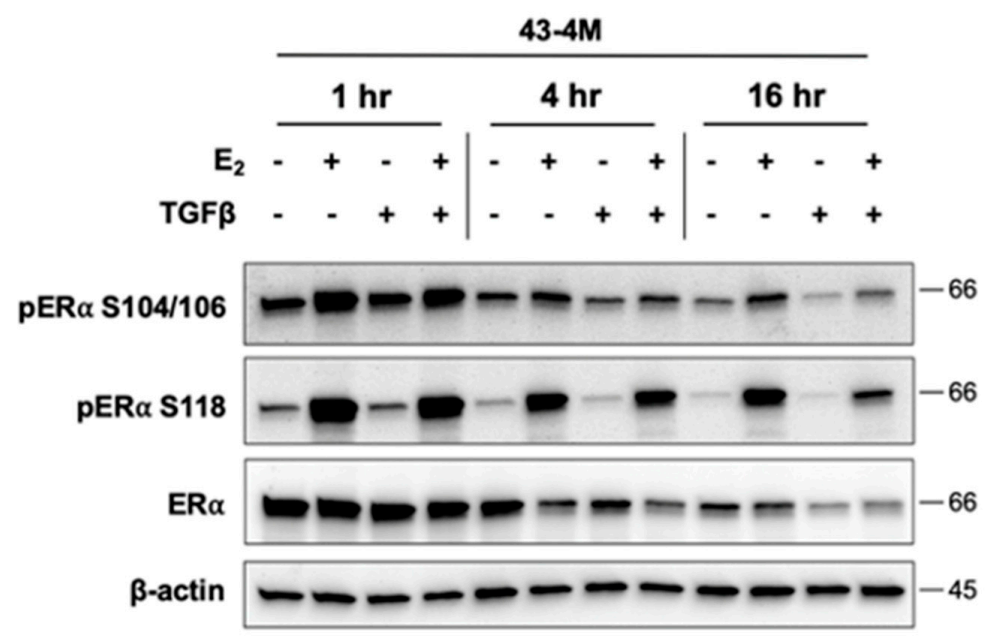

B.

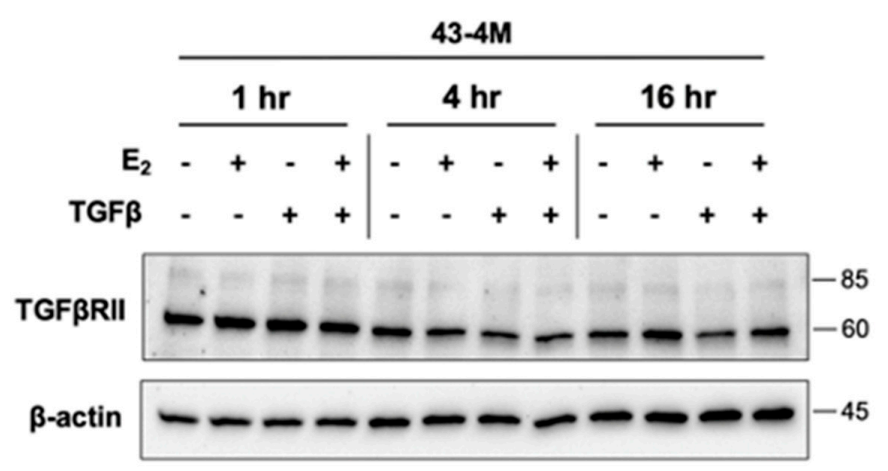

Figure 3. Effects of $E_{2}$ and TGF $\beta$ on ER $\alpha$ activation and TGF $\beta$ RII expression of BMET-derived $\mathrm{ER}+$ breast cancer cells. (A) Constitutive and $\mathrm{E}_{2}$-stimulated (S104/106 and S118 phosphorylated) $\mathrm{ER} \alpha$ and (B) TGF $\beta$ RII expression in 43-4M cells maintained in $\mathrm{E}_{2}$-deplete media for 4 days prior to simultaneous treatment with $\mathrm{E}_{2}\left(10^{-8} \mathrm{M}\right)$ and/or TGF $\beta(5 \mathrm{ng} / \mathrm{mL})$ for the indicated times. 
A.

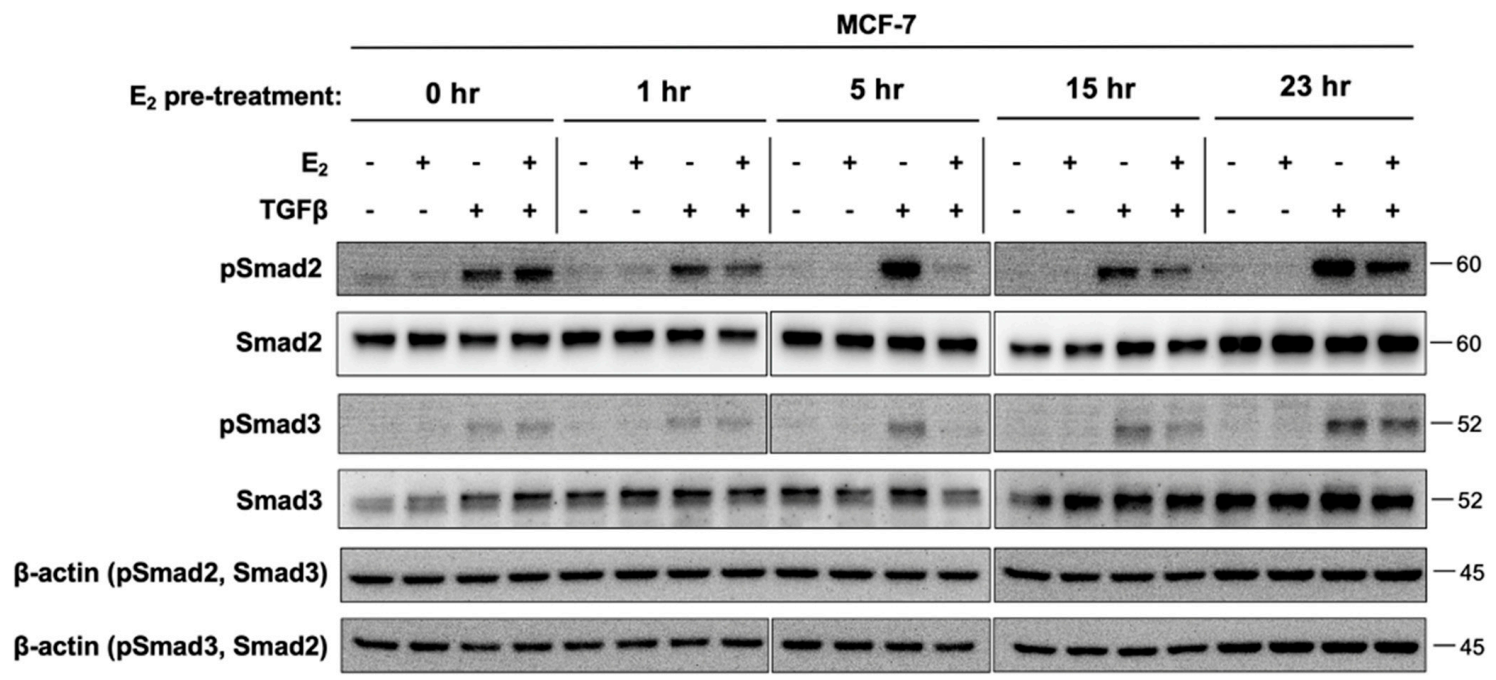

B.

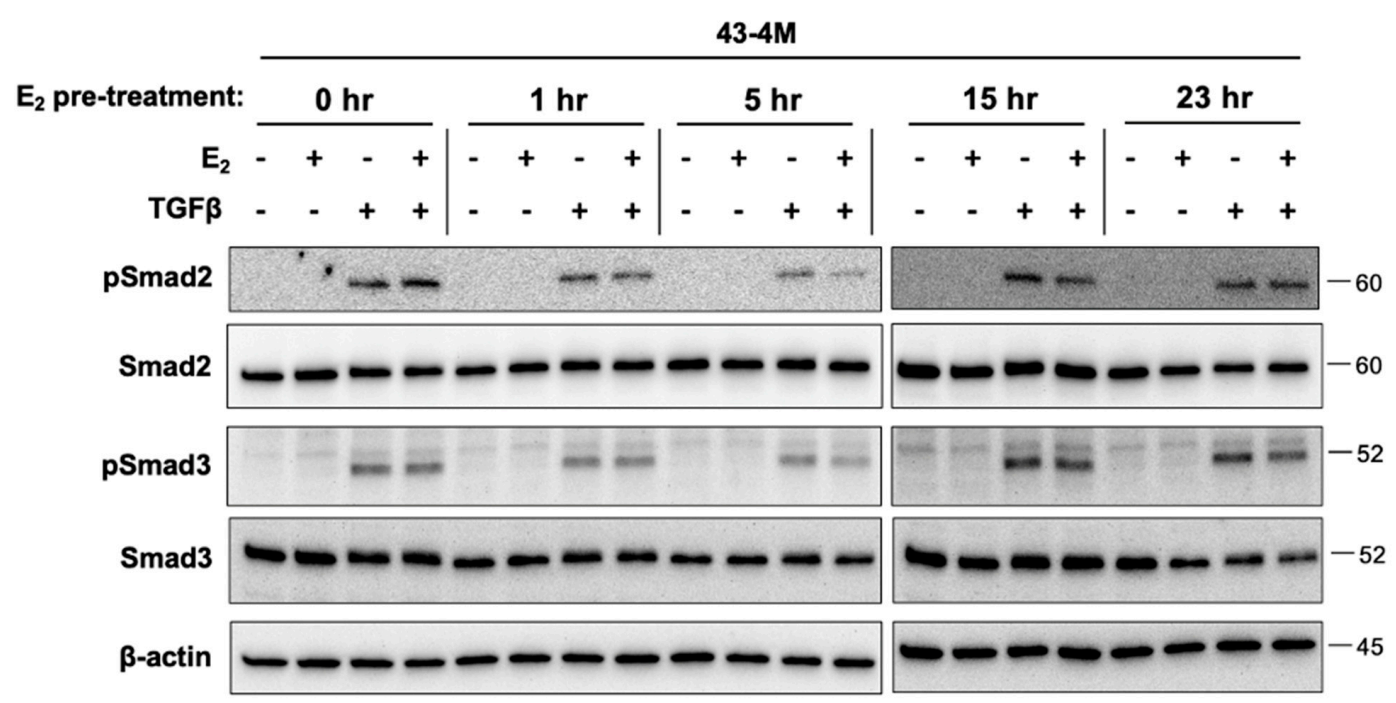

Figure 4. $\mathrm{E}_{2}$ transiently decreases TGF $\beta$-induced Smad signaling in bone-tropic ER+ breast cancer cells. Smad2/3 expression and TGF $\beta$-stimulated ( $5 \mathrm{ng} / \mathrm{mL}$ for $1 \mathrm{~h}$ ) Smad2 and Smad3 phosphorylation in (A) MCF-7 and (B) MCF-7 BMET-derived 43-4M cells maintained in $\mathrm{E}_{2}$-deplete media for 4 days prior to stimulation with $\mathrm{E}_{2}\left(10^{-8} \mathrm{M}\right) \mathrm{vs}$. $\mathrm{E}_{2}$-deplete media for the indicated times prior to addition of TGF $\beta(5 \mathrm{ng} / \mathrm{mL})$ for one hour. Note, early $(0-5 \mathrm{~h})$ vs. late times (15-23 h) were run on two separate blots.

\subsection{Effects of $E_{2}$ and/or TGF $\beta$ on Pro-Metastatic PTHrP Secretion from ER+Cells}

PTHrP secretion, which we previously demonstrated to be $E_{2}$ inducible via ER $\alpha$ in MCF-7 cells [12] and is TGF $\beta$ inducible via Smad signaling in some bone-tropic ERbreast cancer cell lines [13-15,43], was also induced by TGF $\beta$ in bone-tropic MCF-7 cells, demonstrating additive effects when combined with $\mathrm{E}_{2}$ (Figure $5 \mathrm{~A}$, left panel). However, in ER+ cells that did not form osteolytic BMETs (T47D and ZR-75-1), PTHrP levels were near or at the limit of detection and were not altered by $\mathrm{E}_{2}$ or TGF $\beta$, alone or in combination (Figure 5A, middle and right panels). In ER+ cells isolated from ER+ BMETs (38-2M, $43-4 \mathrm{M}, 56 \mathrm{M}$, and $61 \mathrm{M}$ derived from MCF-7 cells, or 84-2MJ derived from MCF-7J cells), PTHrP secretion remained $E_{2}$ and TGF $\beta$ inducible, with additive effects in combination (Figure 5B,C). Notably, in ER+ cells isolated from BMETs, PTHrP secretion (constitutive or stimulated in response to $E_{2}, T G F \beta$, and/or the combination) was higher as compared with MCF-7 or MCF-7J tumor cells initially inoculated (Figure 5B,C). 
A.
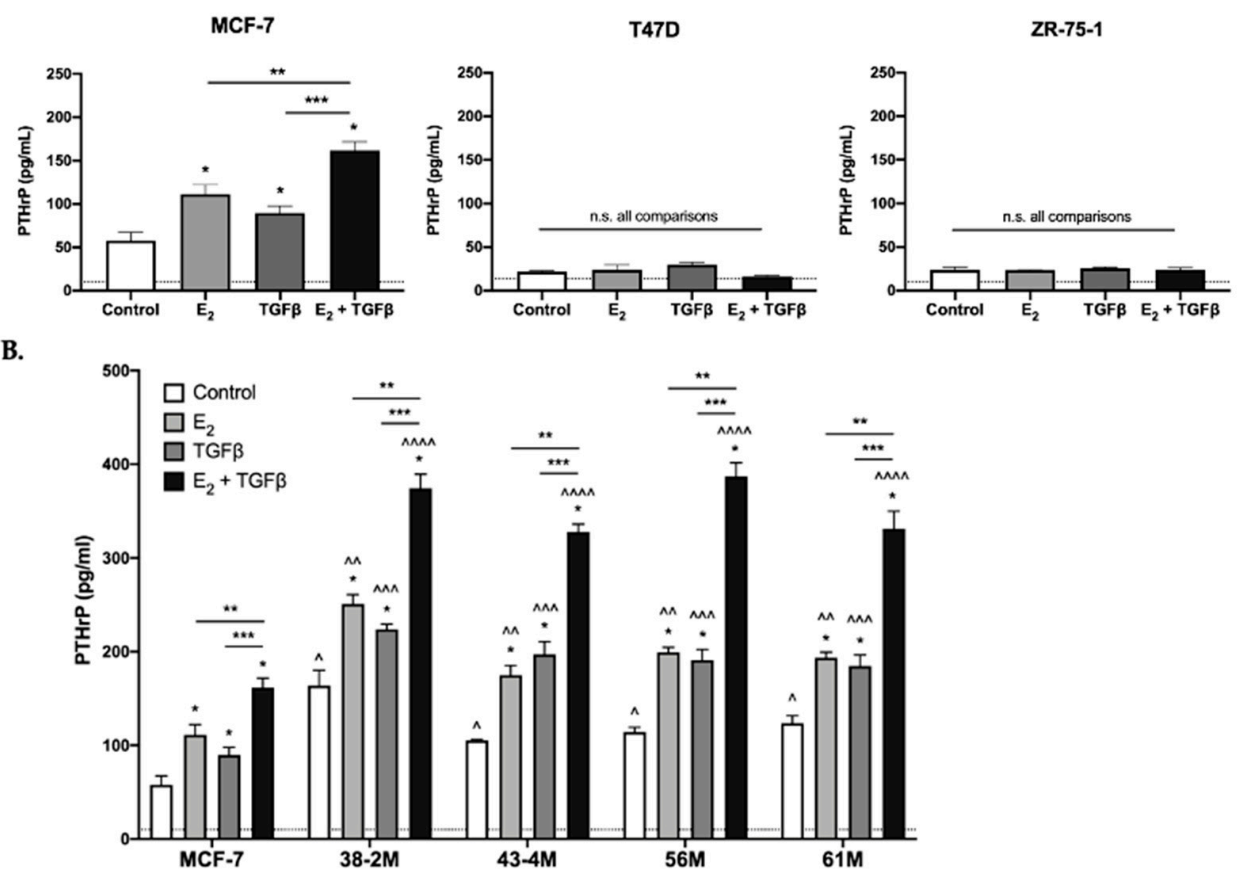

C.

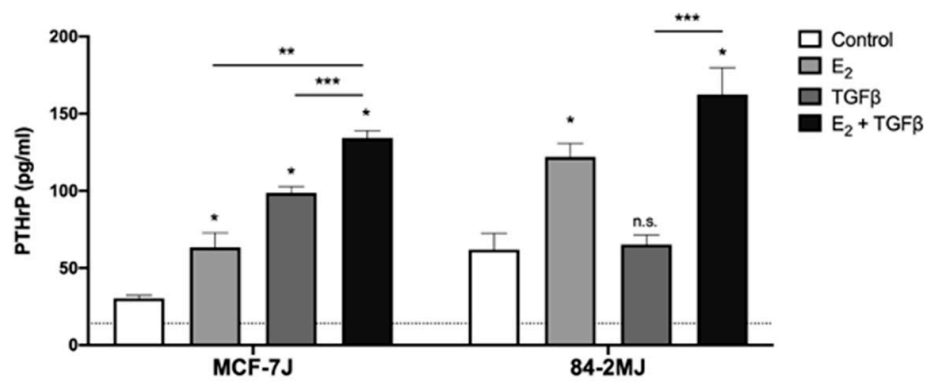

Figure 5. $\mathrm{E}_{2}$ and/or TGF $\beta$-inducible tumor secretion of osteolytic factor PTHrP. Osteolytic PTHrP secretion from (A) ER+ MCF-7, T47D, or ZR-75-1 cells; (B) MCF-7 vs. MCF-7 BMET-derived ER+ tumor cells (38-2M, 43-4M, 56M, 61M); (C) MCF-7J vs. MCF-7J BMET-derived (84-2MJ) tumor cells. Cell were estrogen-depleted prior to stimulation with $\mathrm{E}_{2}\left(10^{-7} \mathrm{M}\right)$ and/or TGF $\beta(5 \mathrm{ng} / \mathrm{mL})$ vs. $\mathrm{E}_{2}$-deplete media alone for 48 (MCF-7, MCF-7-derived, and ZR-75-1 cells) or $72 \mathrm{~h}$ (T47D, MCF-7J, and $84-2 \mathrm{MJ})\left(n=3-4\right.$ /group). Cell number (by MTT assay) was not altered by $\mathrm{E}_{2}$ or TGF $\beta$ treatment under the conditions of the experiment (data not shown). ${ }^{*} p \leq 0.05$ vs. media control, ${ }^{* *} p \leq 0.05 \mathrm{E}_{2}$ vs. $\mathrm{E}_{2}+\mathrm{TGF} \beta,{ }^{* * *} p \leq 0.05 \mathrm{TGF} \beta$ vs. $\mathrm{E}_{2}+\mathrm{TGF} \beta$, or not significant (n.s.), as measured by one-way ANOVA with Holm-Sidak's post hoc test. ${ }^{\wedge} p \leq 0.05$ vs. MCF-7 control, ${ }^{\wedge} p \leq 0.01$ vs. MCF-7 with $\mathrm{E}_{2},{ }^{\wedge \wedge} p \leq 0.0001$ vs. MCF-7 with TGF $\beta,{ }^{\wedge \varkappa} p \leq 0.0001$ vs. MCF-7 with $\mathrm{E}_{2}+\mathrm{TGF} \beta$, as measured by two-way ANOVA with Dunnett's post hoc test. Assay sensitivities are indicated by dotted lines.

\subsection{Effect of $E_{2}$ and/or TGF $\beta$ on Non-Smad Signaling Pathways in Bone-Tropic ER+Cells}

Because ER and TGF $\beta$ RII can each signal via shared non-canonical MAPK pathways, in addition to canonical effects on gene transcription via nuclear ER and TGF $\beta$-stimulated Smad pathways, whose combined effects, for example, contribute to TGF $\beta$-stimulated PTHrP secretion in bone-tropic ER- MDA-SA cells [24], the role of MAPK signaling was evaluated in $\mathrm{E}_{2}$ and/or TGF $\beta$ stimulated bone-tropic ER+ cells. MAPK signaling, as assessed by phosphorylation of second messengers p38, JNK1/2, and ERK1/2, was active at baseline in bone-tropic ER+ BMET-derived 43-4M cells (Figure 6A). $\mathrm{E}_{2}$ and TGF $\beta$ each further induced p38 and ERK activation at early ( $5 \mathrm{~min}$ ) times, while only TGF $\beta$ (alone or in combination with $\mathrm{E}_{2}$ ) increased $\mathrm{p} 38$ and ERK activation at later $(16 \mathrm{~h}$ ) times (Figure 6A). Interestingly, at $10 \mathrm{~min}, \mathrm{ERK}$ activation tended to transiently decrease in response to $\mathrm{E}_{2}$ 
and / or TGF $\beta$ (Figure 6A). Baseline JNK activation, in contrast, was minimally altered at any time in response to treatment with $\mathrm{E}_{2}$ and/or TGF $\beta$ (Figure $6 \mathrm{~A}$ ). Blockade of p38 or JNK activation by inhibitor pretreatment (SB2020190 or SP600125, respectively) appeared to partially block stimulated secretion of PTHrP by $\mathrm{E}_{2}, \mathrm{TGF} \beta$, or the combination (Figure $6 \mathrm{~B}$ ), while ERK inhibition (by SCH772984) was without effect (data not shown). However, after taking into account reductions in constitutive secretion by inhibitors of p38 or JNK (Figure 6B), no inhibitory effects remained (data not shown). Thus, MAPK pathways, while differentially activated by these two agents, had minimal, if any, role in mediating $\mathrm{E}_{2}+$ /TGF $\beta$ inducible PTHrP secretion in BMET-derived ER+ cells.
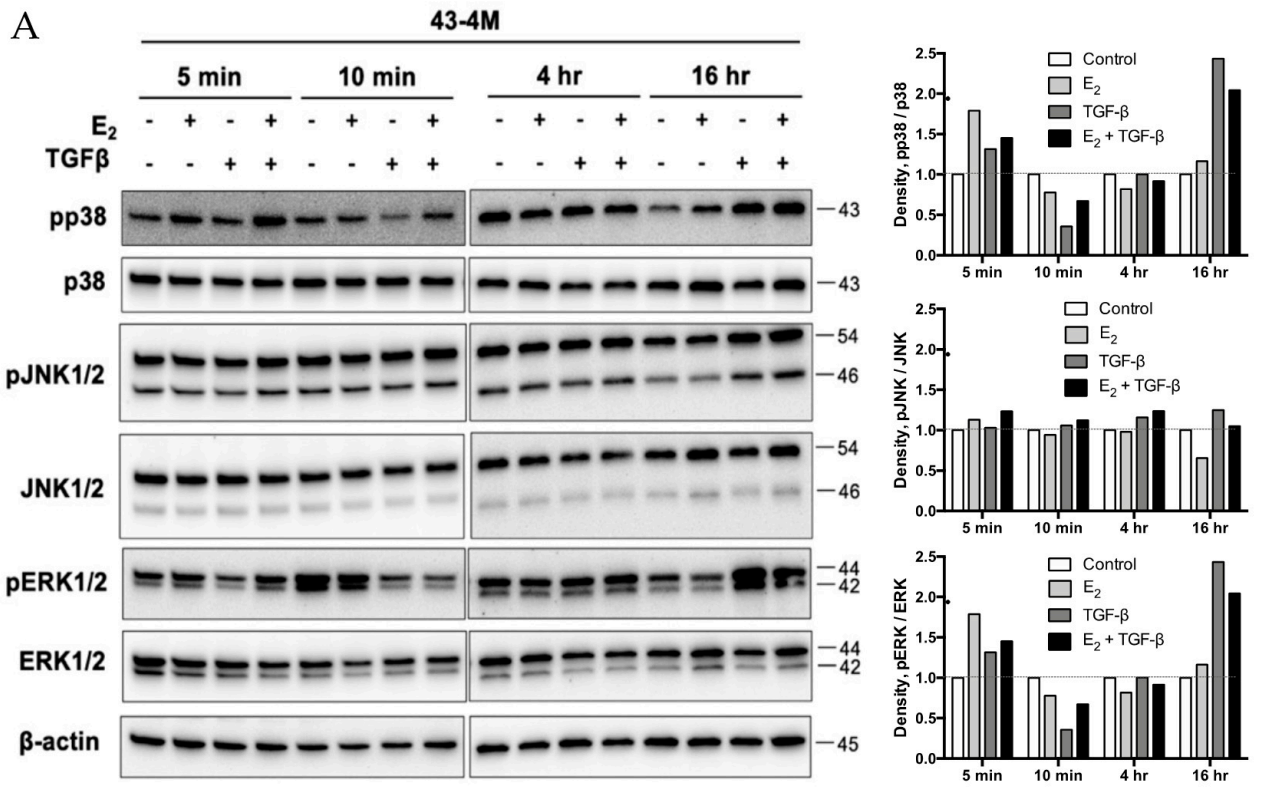

B

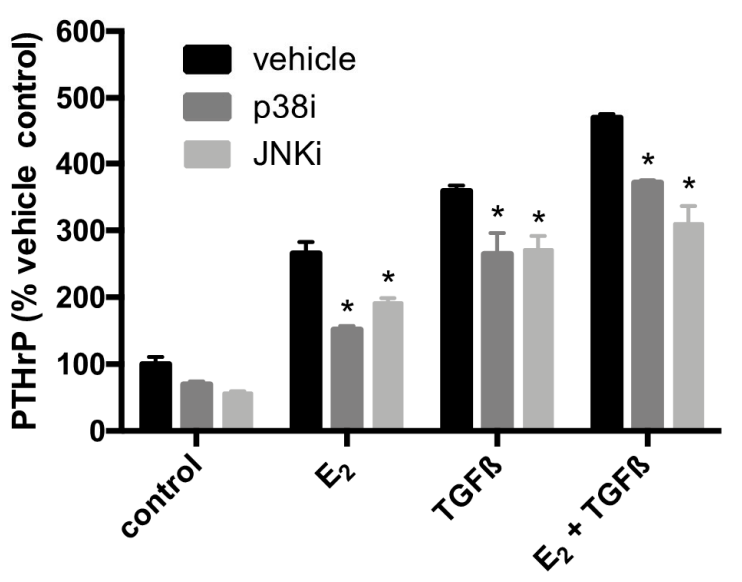

Figure 6. Effect of $E_{2}$ and/or TGF $\beta$ on MAPK signaling. (A) Western analysis of MAPK (p38, ERK1/2, and JNK1/2) protein expression and activation (phosphorylation) in $43-4 \mathrm{M}$ cells maintained for 4 days in $\mathrm{E}_{2}$-deplete media prior to concurrent treatment with $\mathrm{E}_{2}\left(10^{-8} \mathrm{M}\right)$ and/or TGF $\beta(5 \mathrm{ng} / \mathrm{mL})$ for indicated times (left panel). Note, early (5-10 min) vs. late times (4-16 h) were run on two separate blots. Densitometric analysis of MAPK phosphorylation levels relative to MAPK protein levels, normalized to control for each time point, is also included (right panel); (B) inducible PTHrP secretion in 43-4M. M cells maintained for 4 days in $\mathrm{E}_{2}$-deplete media prior to $52 \mathrm{~h}$ of treatment with $\mathrm{E}_{2}\left(10^{-8} \mathrm{M}\right)$ and/or TGF $\beta$ (5 ng/mL) vs. media control, with or without $1 \mathrm{~h}$ pretreatment with p38 inhibitor SB202190 (10 $\mu \mathrm{M})$ or JNK inhibitor SP600125 (25 $\mu \mathrm{M})$ vs. vehicle ( $n=4-8$ /group). ${ }^{*} p \leq 0.01$, inhibitor vs. vehicle with $\mathrm{E}_{2}$ and/or TGF $\beta$ treatment by two-way ANOVA with Sidak's post hoc test. Inhibitors significantly decreased constitutive secretion (see controls) by $t$ test $(p<0.05)$, but not by ANOVA. When re-expressed as \% change relative to constitutive levels, no inhibitory effects of SM202190 or SP600125 remained (data not shown). Cell viability, as assessed by MTT assay, were not different between cell lines or altered by MAPK inhibitor, $\mathrm{E}_{2}$, or TGF $\beta$ treatment (data not shown). 
Because signaling via mTOR can facilitate nuclear ER signaling and is TGF $\beta$-responsive [44-47], mTOR signaling was also assessed in $\mathrm{E}_{2}$ and/or TGF $\beta$ stimulated bone-tropic ER+ cells Signaling via mTOR, as assessed by S2481 and S2448 phosphorylation, was active at baseline in bone-tropic ER+ BMET-derived 43-4M cells (Figure 7A) and further stimulated by $\mathrm{E}_{2}$ at early $(1 \mathrm{~h})$ but not late times $(16 \mathrm{~h})$ (with or without TGF $\beta$, Figure $7 \mathrm{~A}$ ), while TGF $\beta$ alone was without effect. Consistent with isolated activation of mTOR by $E_{2}$, the mTOR inhibitor, rapamycin, significantly reduced PTHrP secretion stimulated by $\mathrm{E}_{2}$, alone or in combination with TGF $\beta$, while stimulation of PTHrP by TGF $\beta$ alone was unchanged (Figure 7B). Thus, mTOR signaling appeared specific to $\mathrm{E}_{2}$ and contributed to $\mathrm{E}_{2}$ inducible PTHrP secretion in BMET-derived ER+ cells.

A.

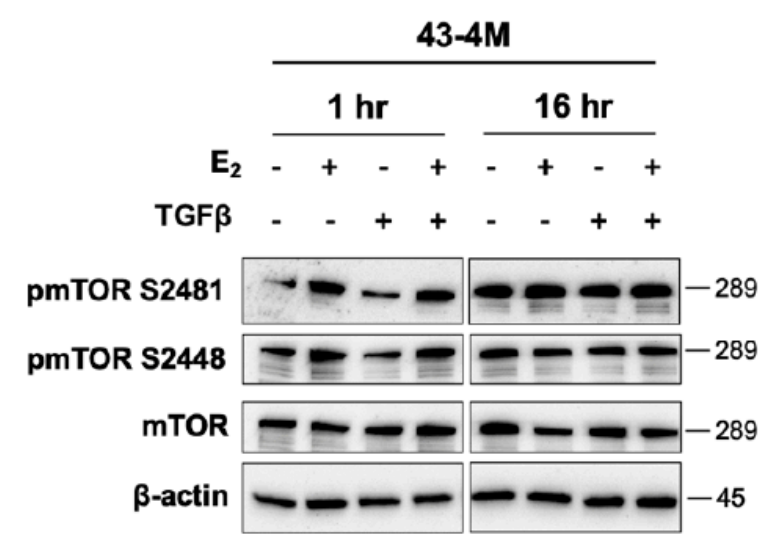

B.

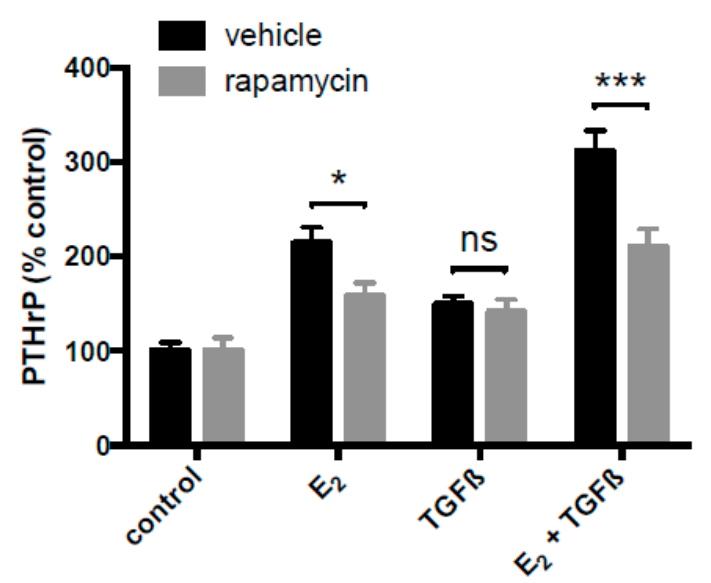

Figure 7. Effect of $E_{2}$ and/or TGF $\beta$ on mTOR signaling. (A) mTOR expression and activation (phosphorylation of S2481 and S2448) in 43-4M cells treated concurrently with $\mathrm{E}_{2}$ and/or TGF $\beta$ for 1 or $16 \mathrm{~h}$, following 4 days of $\mathrm{E}_{2}$ depletion; (B) inducible PTHrP secretion in 43-4M cells maintained for 4 days in $\mathrm{E}_{2}$-deplete media, then, treated for $52 \mathrm{~h}$ with $\mathrm{E}_{2}\left(10^{-8} \mathrm{M}\right)$ and /or TGF $\beta(5 \mathrm{ng} / \mathrm{mL})$, or media control ( $n=4-8$ /group), with or without $1 \mathrm{~h}$ pretreatment with rapamycin $(1 \mathrm{nM})$. Because rapamycin decreased constitutive PTHrP secretion by $46 \%(p<0.05)$, data are expressed as $\%$ change relative to constitutive (control) levels. ${ }^{*} p \leq 0.05$ or ${ }^{* * *} p<0.001$ for rapamycin vs. vehicle with $\mathrm{E}_{2}$ and/or TGF $\beta$ treatment, by two-way ANOVA with Sidak's post hoc test.

\subsection{Role of TGF $\beta$ in Osteolytic ER+ BMET Progression In Vivo}

The $E_{2}$ dependence of tumor-associated osteolysis in ER+ BMETs formed in vivo by MCF-7 cells and ER-mediated secretion of PTHrP from these same cells, has previously been reported [12]. Given the correlation documented here between in vivo osteolytic ER+ BMET formation and (1) tumoral Smad-mediated TGF $\beta$ signaling, as well as (2) TGF $\beta$-inducible tumoral PTHrP secretion, additive to the stimulatory effects of $E_{2}$, a 
possible contributing role for TGF $\beta$ in driving osteolytic estrogen-dependent ER+ BMET progression in vivo was assessed. Using the same pan-TGF $\beta$ neutralizing antibody (1D11) and dosing scheme successfully used to block osteolytic BMET progression in preclinical models of ER- BMETs dependent on tumoral TGF $\beta$ signaling [30-32], experiments were undertaken to assess the in vivo effects of TGF $\beta$ neutralization on ER+ BMET progression in $\mathrm{E}_{2}$-treated nude mice inoculated with ER+ BMET-derived $43-4 \mathrm{M}$ cells, which secreted high levels of TGF $\beta$-inducible PTHrP, alone or in combination with $\mathrm{E}_{2}$, unrelated to MAPK or mTOR signaling, suggesting a possible role for canonical Smad signaling in mediating the TGF $\beta$ effect.

In the absence of $E_{2}$ supplementation, osteolytic BMETs did not develop in mice inoculated with $43-4 \mathrm{M}$ cells (data not shown), but with $\mathrm{E}_{2}$ supplementation, osteolytic BMETs reached an incidence of $100 \%$ within 4 weeks of inoculation (Figure $8 \mathrm{~A}$ inset, vehicle controls). Treatment with an IgG control antibody did not statistically alter osteolytic BMET incidence or size (Figure 8A and inset). Treatment with the pan-TGF $\beta$ neutralizing antibody (1D11) significantly reduced both osteolytic ER+ BMET lesion incidence and size in $E_{2-}$ supplemented mice as compared with vehicle or IgG controls (Figure 8A and inset), with the incidence decreased by $31 \%(p \leq 0.05)$ and lesion size by $92 \%(p \leq 0.0001)$ as compared with IgG control. TGF $\beta$-neutralizing antibody treatment also decreased BMET tumor burden, as measured histologically by cytokeratin-positive tumor area, by $65 \%(p<0.05)$ vs. combined control groups, although the trend comparing vehicle or IgG control groups individually to 1D11 did not reach statistical significance (Figure 8B). Of note, ER+ 43-4M cell proliferation was significantly inhibited by TGF $\beta$ treatment in vitro (Figure $8 \mathrm{C}$ ), as has also been reported for bone-tropic ER-cells [22,31,32]. Thus, neutralization of TGF $\beta$ would be anticipated to increase tumor cell proliferation, which runs contrary to in vivo findings. Thus, reduced BMET size upon neutralization of TGF $\beta$ could not be attributable to direct TGF $\beta$ effects on tumor cell proliferation. Importantly, initiation of TGF $\beta$ neutralizing antibody treatment ( $24 \mathrm{~h}$ post inoculation) occurred after tumor dissemination to bone had already occurred and stabilized (e.g., $34.2 \pm 7.5$ vs. $36.7 \pm 6.043-4 \mathrm{M}$ tumor cells per $10^{6}$ marrow cells, respectively, were detected in hind limbs $24 \mathrm{vs} .72 \mathrm{~h}$ post inoculation in vehicle-treated mice $(p>0.05, n=4$ /group)). Lastly, because ER+ $43-4 \mathrm{M}$ cells did not form non-osseus metastases, effects of TGF $\beta$ neutralization on metastatic progression at other sites could not be assessed.

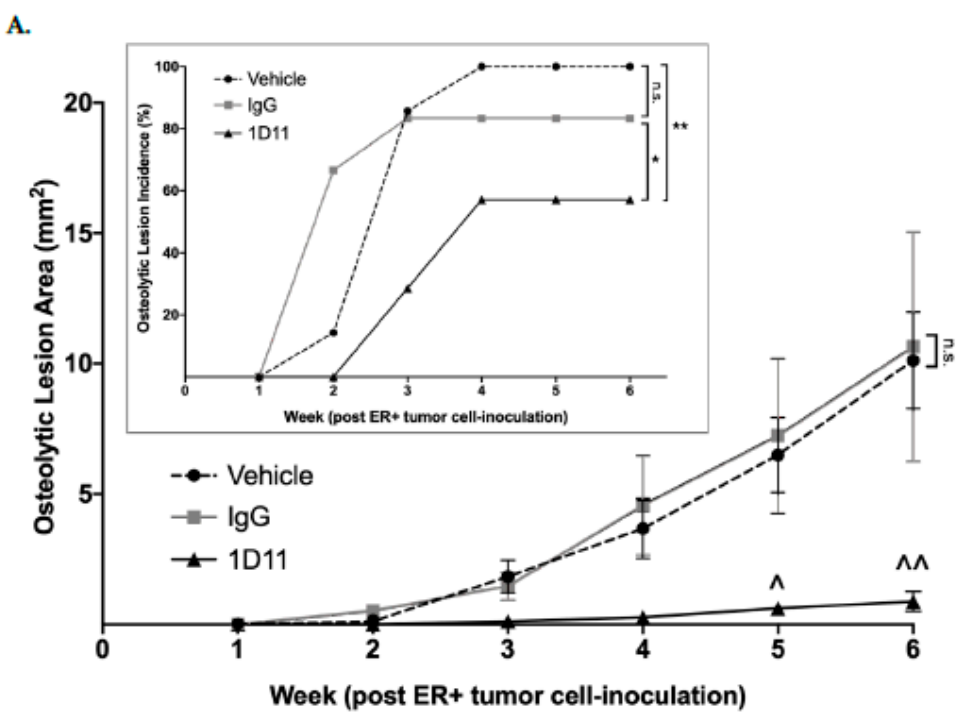

Figure 8. Cont. 
B.

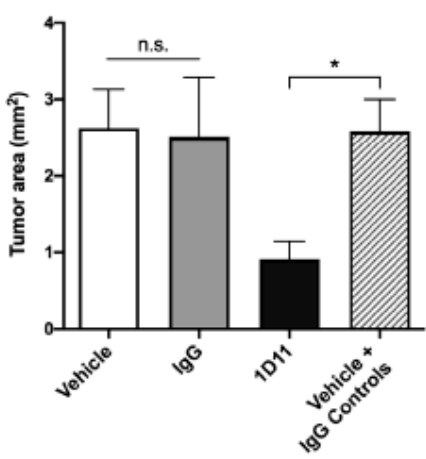

c.

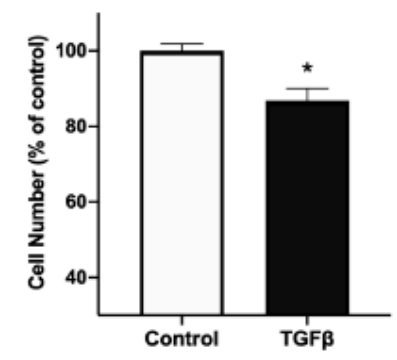

D.

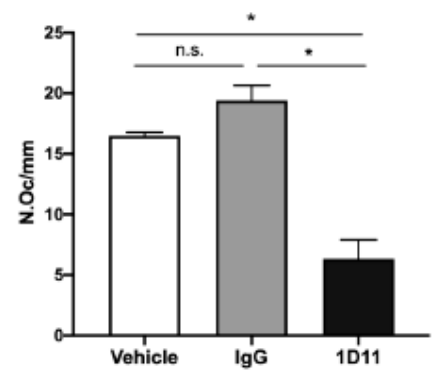

E.

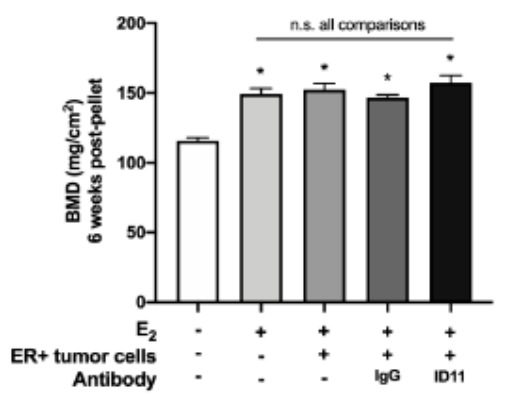

Figure 8. Effect of TGF $\beta$ inhibition on ER+ osteolytic BMET progression in vivo. (A) Osteolytic BMET lesion area and incidence (inset), as measured by radiographs and confirmed by histology, in hind limbs of $E_{2}$-supplemented mice inoculated with 43-4M cells and treated 3 times/week for 6 weeks with TGF $\beta$-neutralizing 1D11, isotype-matched control IgG $(10 \mathrm{mg} / \mathrm{kg})$, or vehicle $(n=6-7 /$ group $)$. ${ }^{\wedge} p \leq 0.05$ and ${ }^{\wedge} p \leq 0.0011 \mathrm{D} 11$ vs. vehicle or IgG controls at indicated timepoints, n.s. IgG vs. vehicle, by two-way ANOVA with Tukey's post-test; ${ }^{*} p \leq 0.051 \mathrm{D} 11 \mathrm{vs.} \mathrm{IgG,}{ }^{* *} p \leq 0.051 \mathrm{D} 11$ vs. vehicle, n.s. IgG vs. vehicle, by Gehan-Breslow-Wilcoxon test; (B) cytokeratin-positive $43-4 \mathrm{M}$ tumor area in hind limbs 6 weeks post-ER+ tumor cell inoculation in 1D11-treated mice vs. controls (IgG or vehicle-treated). Total tumor area per leg was unchanged by IgG treatment vs. vehicle ( $n=7-13$ /group), therefore, values were combined and compared to 1D11-treated mice. ${ }^{*} p \leq 0.05$ by Student's $t$-test; (C) effect of TGF $\beta(5 \mathrm{ng} / \mathrm{mL})$ on $43-4 \mathrm{M}$ cell proliferation, as determined by MTT assay ( $n=8 /$ group), when cells were plated at a low density $\left(6 \times 10^{4}\right.$ cells $\left./ 2 \mathrm{~cm}^{2}\right)$ to ensure treatments were added during the exponential growth phase. ${ }^{*} p \leq 0.01$ vs. media control by $t$-test; (D) osteoclast number at the tumor-bone interface (N.Oc/mm) in tibiae from $\mathrm{E}_{2}$-supplemented, 43-4M cell-inoculated mice treated with $1 \mathrm{D} 11 \mathrm{vs.} \mathrm{IgG} \mathrm{or} \mathrm{vehicle} \mathrm{(} n=3-7 /$ group). ${ }^{*} p \leq 0.0051 \mathrm{D} 11$ vs. vehicle or IgG, not significant (n.s.) vehicle vs. IgG, by one-way ANOVA with Tukey's post hoc test; (E) areal bone mineral density of proximal femurs in naïve or $E_{2}(0.72 \mathrm{mg})$-supplemented mice 6 weeks following supplementation as compared with $\mathrm{E}_{2}$-supplemented mice inoculated with $43-4 \mathrm{M}$ cells and treated with 1D11 vs. IgG or vehicle 3 times/week for 6 weeks ( $n=4-7 /$ group). ${ }^{*} p \leq 0.05$ vs. control, with no significant differences (n.s.) between non-control groups by one-way ANOVA with Holm-Sidak's post hoc test.

Consistent with the significant decrease in ER+ BMET-associated osteolysis documented with 1D11 treatment, osteoclast formation at the tumor-bone interface was also significantly reduced (65\%) in mice treated with 1D11 (vs. controls) (Figure 8D). While inhibition of ER- BMET progression by 1D11 antibody treatment in mouse models lacking $\mathrm{E}_{2}$ supplementation is accompanied by significant anabolic effects of TGF $\beta$ neutralization on the bone microenvironment $[30,32,48]$, areal bone mineral density (aBMD) of the proximal femur, a site devoid of ER+ BMETs in all treatment groups (data not shown), was not altered by TGF $\beta$ neutralization above levels already induced by $\mathrm{E}_{2}$ alone (Figure $8 \mathrm{E}$ ), an effect that we have previously demonstrated to be attributable to enhanced anabolism $[12,49]$. 


\section{Discussion}

Despite the well-characterized function of tumoral TGF $\beta$ signaling in driving the "vicious cycle of osteolysis" demonstrated in preclinical models of ER- breast cancer BMETs, little is known about the role of tumoral TGF $\beta$ signaling in ER+ BMETs, a subtype that comprises over $70 \%$ of breast cancer BMETs [5-8]. TGF $\beta 1$ is expressed by bone myeloid cells $[29,30,50-53]$, is the predominant TGF $\beta$ isoform in bone [54,55], and is released from bone matrix stores into the bone microenvironment during osteolysis, an event that dominates in the majority of breast cancer BMETs [56], regardless of the tumor subtype. Prior in vitro evidence has suggested that $\mathrm{E}_{2}$ could abate TGF $\beta$ signaling in breast cancer cells, and evidence of reciprocal expression of ER $\alpha$ and TGF $\beta R$ in aggressive breast cancer cells has also been reported [34,35,37-40], suggesting that the emergence of TGF $\beta$-targeted therapies for advanced stage cancers [21,33] could prove ineffective or less effective for patients with ER+ BMETs, which comprise the majority of breast cancer BMETs.

Contrary to this a priori hypothesis, in the studies presented here, TGF $\beta$ was in fact demonstrated to be a necessary driver of ER+ breast cancer osteolytic BMET progression in an $E_{2}$-dependent ER+ model where tumor-associated osteolysis and osteolytic BMET progression are also dependent on tumoral ER signaling [12]. In vivo inhibition of microenvironmental TGF $\beta$ decreased ER+ tumor osteolytic progression and tumor burden, an effect unlikely to be due to changes in tumor cell dissemination, as treatment began $24 \mathrm{~h}$ post tumor inoculation after ER+43-4M cells had already disseminated to bone [12]; nor was the lower tumor burden upon TGF $\beta$ neutralization likely attributable to a loss of direct effects of TGF $\beta$ on tumor cell proliferation given TGF $\beta$ 's in vitro growth suppressive effects on luminal ER+ 43-4M cells, which are also consistent with anti-proliferative effects of TGF $\beta$ in bone-tropic ER-cells [22]. Instead, anti-osteolytic effects of TGF $\beta$ neutralization appear to be driving the reduction in osteolytic ER+ BMETs here, as in ER-models. The significant $(65 \%)$ decrease in osteoclasts at the tumor-bone interface of ER+ BMETs observed in the 1D11 treatment group in parallel with profound (92\%) inhibition of osteolytic lesion progression recapitulates results found in ER- osteolytic BMET preclinical models treated with the same TGF $\beta$-neutralizing antibody used here [30-32]; TGF $\beta$ R kinase inhibitors [30-32]; or with tumor-specific inhibition of Smad-mediated TGF $\beta$ signaling $[22,27,28,57]$. As previously noted, isolated blockade of TGF $\beta$ signaling in osteoclast precursors can also contribute to protective effects of TGF $\beta$ neutralization in osteolytic ER- BMET models where tumoral effects of TGF $\beta$ signaling are also operative, albeit with more modest and variable effects on osteolytic progression and osteoclast number as compared with selective inhibition of tumoral Smad-mediated TGF $\beta$ signaling [29,30,32]. Thus, it is possible that the anti-osteolytic effect of TGF $\beta$ neutralization documented here for ER+ BMETs may similarly be attributable to combined inhibition of tumoral and myeloid cell TGF $\beta$ signaling. However, running counter to this notion, in a BMET model using TGF $\beta$ RII null ER+ MCF-7 variants lacking Smad signaling, which to our knowledge, is the only other study to examine a role for TGF $\beta$ in ER+ BMET, 1D11 antibody treatment did not alter progression of ER+ BMETs, which, interestingly, also had few tumor-associated osteoclasts, suggesting that myeloid TGF $\beta$ signaling may be insufficient to drive osteolytic BMET progression in the absence of tumoral TGF $\beta$ signaling [36].

The likely dependency of osteolysis and BMET progression in this $\mathrm{E}_{2}$-dependent ER+ model on tumoral TGF $\beta$ signaling ran counter to preexisting data suggesting possible suppression of TGF $\beta$ signaling in ER+ breast cancer cells. However, these in vivo results were in complete accord with additional key experimental findings, including the association of ER+ osteolytic bone metastatic behavior with TGF $\beta$ induction of canonical Smad signaling (MCF-7- and MCF-7J cells). While all ER+ cells expressed TGF $\beta$ RII and TGF $\beta$ RI at levels similar to those reported for ER- bone tropic cells, TGF $\beta$-simulated Smad2/3 activation was lacking in cells that did not form $\mathrm{E}_{2}$-dependent osteolytic BMETs in vivo, due in part to reduced Smad3 expression in these cell lines. This suggestion of a potential Smad3 dependency for ER+ osteolytic BMET progression is interesting given prior similar evidence in bone-tropic ER- cells of a greater role for tumoral Smad3 (vs. Smad2) in TGF $\beta$-induction 
of PTHrP or other key TGF $\beta$-inducible target genes involved in osteolytic ER-BMETs, as well as slower in vivo osteolytic BMET progression following knock down of tumoral Smad3 expression $[24,58]$. In addition, clinical evidence presented here of co-expression of receptors initiating TGF $\beta$ and $E_{2}$ signaling at higher levels in clinical breast cancer BMETs (vs. primary tumors) is also consistent with a key role of TGF $\beta$ signaling within the bone microenvironment for ER+ tumors, and with other clinical datasets associating TGF $\beta$ RII expression with ER+ tumors [59]. Taken together, these findings suggest that TGF $\beta$-stimulated Smad signaling, which is active in $75 \%$ of clinical BMET $[29,60]$, may be a biomarker and/or necessary driver of osteolysis in ER+ BMETs, the absence of which may account, at least in part, for a lack of progression of osteolysis and tumor expansion in mice inoculated with T47D or ZR-75-1 cells, despite evidence here, and in prior studies, that these tumor cells disseminate to bone [61,62].

Because ER+ tumors have a greater clinical predilection for forming clinical BMETs, which are primarily osteolytic, our laboratory previously queried and documented a role for tumoral ER $\alpha$ signaling in specifically driving BMET osteolysis in the ER+ BMET models studied here, separate from its growth promoting proliferative effects, which are not bone specific [12]. An obvious question, thus, emerges, "In light of this new evidence of TGF $\beta$ dependence for both ER+ and ER- osteolytic BMETs, can the greater predilection of ER+ tumors for forming clinically evident, osteolytic BMETs be due to combined pro-osteolytic effects of tumoral ER and TGF $\beta$ signaling in ER+ breast cancer cells?" As demonstrated here, TGF $\beta$ stimulated Smad signaling was active and specifically associated with bone metastatic potential in ER+ cancer cells, with only transient $\mathrm{E}_{2}$-induced decreases in Smad2/3 activation, which were followed by later $E_{2}$-induced increases in TGF $\beta$ RII expression. Because TGF $\beta$ did not alter ER phosphorylation, a mechanism by which some growth factors after nuclear ER signaling [42], it is possible that additive effects of $E_{2}$ and TGF $\beta$ on secretion of PTHrP, an osteolytic factor overexpressed in breast cancer BMETs vs. other metastatic sites $[17,18]$ with similar overexpression here in ER+ BMET-derived cells, could simply be attributable to separate, but additive effects of canonical Smad-mediated TGF $\beta$ RII and ER signaling (i.e., induction of gene expression by activated nuclear Smads and $E R \alpha)$. However, reports of activated Smad and ER each colocalizing with transcription factor, FOXA1, and/or direct interactions between Smad3 and ER [38] suggest that more complex interactions between canonical TGF $\beta$ RII and nuclear ER $\alpha$ signaling may also drive the progression of osteolytic ER+ metastases in bone, a postulate that awaits further testing. While not studied here, it is also interesting to note that feedforward connections between ligands for these receptors are also possible in bone. While not relevant in $\mathrm{E}_{2}$-supplemented murine models that lack aromatase in bone [63,64], TGF $\beta$-stimulated aromatase expression in human osteoblasts [65] could support local increases in $E_{2}$ surrounding osteolytic ER+ BMETs, thus, further contributing to a vicious cycle tumor-driven osteolysis even in post-menopausal patients.

While MAPK and mTOR signaling were induced independently by $E_{2}$ and/or by TGF $\beta$, only $E_{2}$ induction of mTOR signaling appears to partially mediate $E_{2}$ induction of PTHrP. However, it remains possible that isolated or additive effects of $E_{2}$ and/or TGF $\beta$ on these pathways could mediate other pro-metastatic events. The role of mTOR documented here for $\mathrm{E}_{2}$ stimulation of PTHrP secretion in bone tropic ER+ cells forming osteolytic lesions in vivo is specifically of clinical relevance as recent clinical trials evaluating the efficacy of combining hormone therapy with mTOR inhibitors (such as everolimus) have proven effective in patients with advanced ER+ breast cancer (including those with BMETs), with results reported here possibility providing additional mechanistic insights [66].

There are certain limitations to the studies reported here. Experiments were conducted using established human breast cancer cells lines rather than cells from patient-derived xenografts (PDX) models; while PDX models recapitulate aspects of patient-specific responses across a range of human tumors, ER+ PDXs are reported to have a much lower take rate and tend not to metastasize to bone [67-69]. Furthermore, the necessity of supplementing human xenograft ER+ BMET models with $E_{2}$ to promote tumor growth and 
BMETs [12,61,70-78] causes notable anabolic changes in murine bone $[49,61,72,79]$, which we previously demonstrated to have a stimulatory effect on ER+ BMETs [12], although these effects were independent of tumor-specific, pro-osteolytic effects of $E_{2}$ that also drove ER+ BMET progression in the models described here [12]. However, from an experimental standpoint, this aspect of the ER+ models had the benefit of negating the anabolic effects of TGF $\beta$ inhibition on the bone microenvironment normally seen in naïve or ER- tumorbearing mice $[30,32,48]$. While anabolic effects of TGF $\beta$ neutralization documented in ERmodels lacking $\mathrm{E}_{2}$ supplementation have been postulated to contribute to the protective anti-osteolytic effects of TGF $\beta$ neutralization [32], because TGF $\beta$ neutralization had no such additive anabolic effect here, this can be discounted as a possible contributing factor to the therapeutic efficacy of TGF $\beta$ neutralization in the ER+ model.

While the presence, or absence, of TGF $\beta$-stimulated Smad signaling and PTHrP secretion clearly differentiated ER+ cells that did, or did not, form osteolytic BMETs in vivo, it is likely that TGF $\beta$ signaling was not the only difference contributing to their differential abilities to form BMETs, and the involvement of other tumoral pathways and their interaction with the bone microenvironment waits further testing. However, the ability of in vivo TGF $\beta$ neutralization to significantly decrease ER+ BMETs by targeting osteolysis, and the demonstrated additive effects of ER and TGF $\beta$ RII signaling in driving tumoral secretion of pro-osteolytic factors, such as PTHrP, clearly demonstrate, for the first time, a key role for TGF $\beta$ signaling in driving ER+ osteolytic BMET progression. The additive pro-osteolytic effects of tumoral TGF $\beta$ RII and ER signaling in bone-tropic $\mathrm{ER}+$ cells also suggest a possible mechanism underpinning the clinical observation that bone-disseminated ER+ (vs. ER-) breast cancer cells appear more likely to progress to clinically evident osteolytic BMETs. Further study of specific downstream molecular targets facilitating crosstalk between ER and TGF $\beta$ RII in mediating osteolysis in bone-tropic ER+ cells, particularly in light of the high prevalence of activating ER $\alpha$ mutations in metastatic breast cancer [80,81] may, therefore, provide fertile ground for new therapeutic discoveries to benefit the majority of patients with breast cancer BMETs.

\section{Materials and Methods}

\subsection{Cell Lines}

Human ER+ breast cancer tumor cell lines, MCF-7, T47D, and ZR-75-1 (American Type Culture Collection (ATCC), Manassas, VA, USA), were cultured in $\mathrm{E}_{2}$-replete Dulbecco's modified Eagle's medium (DMEM, Invitrogen, Carlsbad, CA, USA) or RPMI-1640 (Invitrogen), as per ATCC's recommendation, containing $10 \%$ heat-inactivated fetal bovine serum (FBS, Atlanta Biologicals, Flowery Branch, GA, USA), and 1\% penicillin/streptomycin (Thermo Fisher, Waltham, MA, USA) in $37^{\circ} \mathrm{C}$ and $5 \% \mathrm{CO}_{2}$ in a humidified atmosphere. ATCC MCF-7 cells virally transduced to express firefly luciferase [73] (referred to as MCF7J) were a kind gift provided by Dr. Jude Canon, and bone-tropic ER- human MDA-MB-231 (MDA-SA) cells [82] were generously provided by Dr. Theresa Guise. Authentication of all tumor cell lines was verified as previously described [41,43]. Where indicated, human ER+ BMET-derived tumor cells, isolated from hind limbs bearing radiographic evidence of osteolytic BMETs 42 to 56 days post-intracardiac (IC) inoculation, were also studied. To isolate cells, mice were euthanized, and tumor-bearing hind limbs were removed using sterile tools and stripped of connective tissue. Cells, flushed from the marrow of all tibiae and femurs of a single tumor-bearing animal using sterile media with repeated washing and crushing of bone, were combined, transferred into cell-culture dishes, and passaged when adherent tumor cells reached a confluency of $30 \%$ or higher. Tumor cells were passaged two additional times to remove non-immortalized and non-adherent murine cells before establishment of human cell lines (43-4M, 41-1M, 41-2M, 38-2M, 56M, or 61M from MCF-7 cells, or 84-2MJ from MCF-7J cells), which were each authenticated as being MCF-7-derived before use [41,43]. Of note, cell proliferation in $\mathrm{E}_{2}$-replete media over 8 days of incubation, determined by counting of trypsinized cells, was statistically the same in MCF-7 vs. BMET-derived MCF-7 cells, with cell numbers increasing approximately 6-fold. 


\subsection{In Vitro Analysis of ER and TGF $\beta$ Signaling in ER+ Human Breast Cancer Cells}

For analysis of effects of $E_{2}$ and/or TGF $\beta$ on cell signaling by Western, cells were first maintained in $\mathrm{E}_{2}$-deplete media (phenol red-free DMEM, 10\% charcoal-stripped FBS, $200 \mathrm{mM}$ L-glutamine, 1\% penicillin/streptomycin) for 4 days, as previously described [12], prior to treatment for the indicated times with $17 \beta$-estradiol $\left(\mathrm{E}_{2}, 10^{-8} \mathrm{M}\right.$, Sigma-Aldrich, St. Louis, MO, USA) and/or TGF $\beta$ (TGF $\beta 1,5 \mathrm{ng} / \mathrm{mL}$, R\&D Systems, Minneapolis, MN, USA), with treatments either added concurrently or with $\mathrm{E}_{2}$ (vs. vehicle) pretreatment for $1-23 \mathrm{~h}$, as indicated, prior to direct addition of TGF $\beta$. For Western analyses of protein levels and/or activation (phosphorylation), proteins were isolated from whole cell lysates, quantified by Bradford assay (Bio-Rad, Hercules, CA, USA), and analyzed by Western blots with confirmation of even protein loading, as previously described, including assessment of $\beta$-actin $[41,43]$. Blots were probed with primary rabbit antibodies shown in Supplemental Table S1, followed by HRP-conjugated anti-rabbit secondary antibody (\#7074, Cell Signaling Technology [CST], Danvers, MA, USA) and chemiluminescent visualization of SuperSignal West Femto ECL substrate (ThermoFisher). Prestained Protein Marker (\#13953, CST, Danvers, MA, USA), or Biotinylated Protein Ladder followed by anti-biotin HRP-linked secondary antibody (\#7727, CST, Danvers, MA, USA), were used to estimate probed-proteins $\leq 190 \mathrm{kDa}$ in molecular weight, and Precision Plus Protein Standard (\#1610374, Bio-Rad, Hercules, CA, USA) followed by anti-biotin HRP-linked secondary antibody (\#7727, CST, Danvers, MA, USA) was used for probed-proteins $\geq 190 \mathrm{kDa}$. Most blots are representative of $\geq 3$ separate experiments.

For analysis of the tumor-secreted osteolytic factor, PTHrP, cells were plated in 24-well tissue culture plates at a density of $1.3 \times 10^{5}$ cells / well and maintained in $\mathrm{E}_{2}$-deplete media for 4 days followed by treatments with $\mathrm{E}_{2}\left(10^{-7}\right.$ or $10^{-8} \mathrm{M}$, as indicated) and/or TGF $\beta$ ( $5 \mathrm{ng} / \mathrm{mL}$ ), or media control for 48,52 , or $72 \mathrm{~h}$, as indicated (depending on cell line) to optimize detection. For inhibitor experiments, cells were pretreated for $1 \mathrm{~h}$ prior to $\mathrm{E}_{2}$ and/or TGF $\beta$ stimulation with MAPK inhibitors and doses previously demonstrated to block TGF $\beta$-inducible PTHrP secretion from ER- MDA-SA cells [24], using p38 inhibitor SB202190 $[10 \mu \mathrm{M}]$, JNK inhibitor SP600125 [25 $\mu \mathrm{M}]$, ERK inhibitor SCH772984 (1 nM) (Selleckchem, Houston, TX, USA), or with a rapamycin to block mTOR signaling ( $1 \mathrm{nM}$, \#9904, CST, Danvers, MA, USA), using a dose that does not alter MCF-7 cell proliferation [83] (and data not shown). Conditioned media, stored at $-80^{\circ} \mathrm{C}$ after addition of protease inhibitors (Sigma-Aldrich, St. Louis, MO USA), were assayed for secreted PTHrP using a commercial immunoradiometric assay (sensitivity 10-14 pg/mL, Beckman Coulter, Brea, CA, USA). Cell numbers, determined by counting of trypsinized cells, remained statistically unchanged (from day 0 ) after 4 days of $E_{2}$ depletion for every cell line, and a lack of treatment effect under the conditions of the experiments on cell number during the incubation periods for all reported values was also verified using a commercial MTT assay (ATCC, Manassas, VA, USA).

The effects of TGF $\beta$ ( $4 \mathrm{ng} / \mathrm{mL}$, for 4 days) on cell proliferation vs. $E_{2}$-replete media alone were assessed separately in cells plated at a low density $\left(6 \times 10^{4}\right.$ cells/well in a 24-well tissue culture plate) with subsequent analysis of cell number by MTT assay (ATCC, Manassas, VA, USA), as per the manufacturer's protocol.

\subsection{RNA Gene Expression Clinical Primary Breast Tumor vs. BMET-Derived Tumor Cell}

Publicly available RNA expression data (GSE39494) were analyzed to compare ER $\alpha$ vs. TGF $\beta$ RII expression in primary breast cancer tumors from women who developed BMETs vs. breast cancer cells isolated from bones with clinical evidence of metastases. For this dataset [84], RNA isolated from primary breast tumors $(n=5)$ vs. laser captured and micro-dissected tumor cells from flash frozen trephine bone biopsies of non-matched breast cancer patients with BMETs $(n=5)$, as well as universal human reference RNA, were amplified and conjugated to $\mathrm{Cy} 3$ dye prior to hybridization using an Agilent whole human genome microarray platform (Agilent, Santa Clara, CA, USA). Raw expression data from GEO data GSE39494 were analyzed using R scripts and Bioconductor modules. The 
arrays were normalized using normexp background correction and quantile normalization. When multiple probes existed for a gene, these data were averaged. Log2 normalized data were further assessed for differential expression using Limma [85] analysis, which includes correction for multiple hypothesis testing by a false discovery rate method. An adjusted $p$-value $\leq 0.05$ was considered to be significant. For choosing relevant genes a combination of fold change (2-fold up or down) and significant $p$-values were chosen. A R gplots library was utilized to generate heatmaps and plots.

\subsection{Animal Studies}

All animal protocols were approved by the Institutional Animal Care and Use Committee at The University of Arizona (protocol \# 08-149, 9 March 2018) in accordance with the National Institutes of Health Guide for the Care and Use of Laboratory Animals. Four-weekold female Foxn $1^{n u}$ athymic nude outbred mice were purchased from Envigo (Indianapolis, IN, USA) and housed in plastic cages in laminar flow isolated hoods with access to water and autoclaved mouse chow ad libitum. Mice ( $n=5-13 /$ group) were inoculated at 5 weeks of age with $1 \times 10^{5} \mathrm{ER}+$ tumor cells via the left cardiac ventricle (intracardiac, IC) three days post placement of 60 -day extended release $0.72 \mathrm{mg} 17 \beta$-estradiol $\left(\mathrm{E}_{2}\right)$ pellets (Innovative Research of America, Sarasota, FL, USA), as previously described [12,41,49]. In one experiment, similarly $E_{2}$-supplemented mice inoculated with BMET-derived 43$4 \mathrm{M}$ tumor cells ( $n=5-7$ /group) were treated for 6 weeks with a pan-TGF $\beta$-neutralizing murine monoclonal antibody (clone 1D11.16.8, \#BE0057, BioXCell, Lebanon, NH, USA) vs. isotype-matched murine control IgG (M0PC-21 clone, \#BE0083, BioXCell, Lebanon, NH, USA) or vehicle alone (in vivo Pure pH 7.0 dilution buffer, \#IP0070, BioXCell, Lebanon, NH, USA). The TGF $\beta$ neutralizing antibody and dosing scheme (10 mg/kg IP, 3 times/week) matched those previously successfully used to prevent ER- BMET progression [30-32] in preclinical models. Antibody dosing began $24 \mathrm{~h}$ post inoculation, when $43-4 \mathrm{M}$ tumor cells had already disseminated to bone, as was confirmed in a separate experiment, where inoculated Vybrant DiD-labelled 43-4M tumor cells in $\mathrm{E}_{2}$-pelleted mice were isolated from proximal tibias and quantitated as previously described 24 or $72 \mathrm{~h}$ post inoculation [12]. No changes in health status occurred requiring euthanasia in tumor-cell inoculated mice, which were also examined at gross necropsy (or via bioluminescence for MCF-7J cells) 6 weeks post inoculation for non-osseus metastases.

\subsection{Histologic Assessment of ER+BMETs}

Epithelial ER+ breast cancer tumors were immunohistochemically identified in midsagittal (depth of 400-500 um) sections (5-6 $\mu \mathrm{m}$ thick) of decalcified, formalin fixed, paraffinembedded hind leg bones using primary antibodies to pan-cytokeratin (\#Z0622, Agilent Dako, Santa Clara, CA, USA) or human ER $\alpha$ (\#ab108398, Abcam, Cambridge, UK), with tumor area in hind limbs measured in a blinded fashion (and expressed per leg), as previously described $[12,41]$. Hematoxylin and eosin (H\&E) stained sections were also used to assess tumor morphology in bone. Multinucleated tartrate-resistant acid phosphatase (TRAP)-positive osteoclasts lining metaphyseal bone surfaces were quantified at the tumorbone interface of BMET-bearing mice, as previously described [12,41], and are reported as osteoclast number per mm of tumor-bone interface $[12,41,86]$.

\subsection{Bone Imaging}

Osteolytic lesion formation was assessed via weekly radiographs of mouse hind limbs (Faxitron UltraFocus 1000, Faxitron Bioptics, Tucson, AZ, USA) in $E_{2}$-supplemented ER+ tumor cell-inoculated mice over the 6-week course of experiments, which was analyzed as previously described in a blinded fashion by three independent investigators using ImageJ software (NIH) [12,41], with osteolytic BMET incidence or total hind limb radiographic osteolytic lesion area reported per mouse, including animals without osteolytic lesions. Because $E_{2}$ can induce osteolytic osteosarcoma formation in nude mice [49], osteolytic breast cancer BMETs in each hind limb bone were verified by either correlating radiographic 
lesions with cytokeratin-positive human tumors [49,72], or bioluminescence (BLI, Lago, Spectral Instruments Imaging, Tucson, AZ, USA) in the case of mice inoculated with luciferase transfected MCF-7J cells following IP injection with $150 \mathrm{mg} / \mathrm{kg}$ of $15 \mathrm{mg} / \mathrm{mL}$ D-luciferin potassium salt (\#LUCK, Gold Biotechnology, St. Louis, MO, USA) dissolved in sterile PBS. Areal bone mineral density (aBMD) of proximal femurs $(25 \%)$, which were devoid of osteolytic BMETs in tumor-inoculated mice, was assessed by dual-energy X-ray absorptiometry (DXA, Faxitron UltraFocus 1000) in mice 6 weeks post $\mathrm{E}_{2}$-supplementation, with or without tumor inoculation and additional treatments, as indicated.

\subsection{Statistical Analysis}

Data are reported as mean \pm SEM, with statistical significance of two-sided $p$-values defined as $p \leq 0.05$. Statistical differences were determined using Prism 8.0 software (Graphpad, San Diego, CA, USA) for $t$-tests, one- or two-way analyses of variance (ANOVA) with post hoc testing (as indicated), and Gehan-Breslow-Wilcoxon tests. For experiments determining inhibitor effects on $\mathrm{E}_{2}$ - and/or TGF $\beta$-stimulated PTHrP secretion, statistical effects were determined by two-way ANOVA for absolute values and, when inhibitors significantly reduced constitutive secretion $(p<0.01)$, by $t$-test for $E_{2}-$ and/or TGF $\beta$ stimulated increases over constitutive levels in inhibitor-treated (vs. control) cells.

Supplementary Materials: The following are available online at https:/ /www.mdpi.com/article/10 $.3390 /$ ijms22094463/s1.

Author Contributions: Conceptualization, J.N.C. and J.L.F.; Data curation, J.N.C., A.G.K., and R.P.; Formal analysis, J.N.C., J.B.F., R.P., and J.L.F.; Funding acquisition, J.N.C. and J.L.F.; Investigation, J.N.C., J.B.F., S.A.W., and A.G.K.; Methodology, J.N.C., J.B.F., S.A.W., A.G.K., R.P. and J.L.F.; Project administration, J.L.F.; Resources, R.P. and J.L.F.; Software, R.P.; Supervision, J.N.C. and J.L.F.; Validation, J.N.C.; Writing—original draft, J.N.C. and J.L.F.; Writing—review and editing, J.N.C., J.B.F., S.A.W., A.G.K., R.P., and J.L.F. All authors have read and agreed to the published version of the manuscript.

Funding: This work was supported by the National Cancer Institute (NCI) of the National Institutes of Health (NIH) (R03CA181893 and R01CA174926 to J.L.F., T32CA00923, P30CA023074); METAvivor (Translational Research Award, J.L.F.); the Phoenix Chapter of ARCS Foundation (J.N.C.); the Louise Foucar Marshall Foundation Dissertation Fellowship (J.N.C.).

Institutional Review Board Statement: All animal protocols were approved by the Institutional Animal Care and Use Committee at The University of Arizona (protocol \# 08-149, 9 March 2018) in accordance with the National Institutes of Health Guide for the Care and Use of Laboratory Animals.

Informed Consent Statement: Not applicable. Only deidentified publicly available data sets involving humans were used.

Data Availability Statement: A publicly available dataset was analyzed in this study. These data can be found here: https:/ / www.ncbi.nlm.nih.gov/geo/query/acc.cgi?acc=GSE39494 (accessed on 19 March 2021). Other data presented in this study are available upon request from the corresponding author.

Acknowledgments: We would like to acknowledge University of Arizona undergraduates, Madison Egan, Albiya Thomas, and Geethika Ameneni, for their contributions to the data analyses.

Conflicts of Interest: The authors declare no conflict of interest. The funders had no role in the design of the study; in the collection, analyses, or interpretation of data; in the writing of the manuscript, or in the decision to publish the results. 


\section{References}

1. Macedo, F.; Ladeira, K.; Pinho, F.; Saraiva, N.; Bonito, N.; Pinto, L.; Gonçalves, F. Bone metastases: An overview. Oncol. Rev. 2017, 11, 321. [CrossRef]

2. Kozlow, W.; Guise, T.A. Breast Cancer Metastasis to Bone: Mechanisms of Osteolysis and Implications for Therapy. J. Mammary Gland. Biol. Neoplasia 2005, 10, 169-180. [CrossRef]

3. Kuchuk, I.; Hutton, B.; Moretto, P.; Ng, T.; Addison, C.; Clemons, M. Incidence, consequences and treatment of bone metastases in breast cancer patients—Experience from a single cancer centre. J. Bone Oncol. 2013, 2, 137-144. [CrossRef] [PubMed]

4. Pernas, S.; Tolaney, S.M.; Winer, E.P.; Goel, S. CDK4/6 inhibition in breast cancer: Current practice and future directions. Ther. Adv. Med. Oncol. 2018. [CrossRef] [PubMed]

5. Haque, R.; Ahmed, S.A.; Inzhakova, G.; Shi, J.; Avila, C.; Polikoff, J.; Bernstein, L.; Enger, S.M.; Press, M.F. Impact of Breast Cancer Subtypes and Treatment on Survival: An Analysis Spanning Two Decades. Cancer Epidemiol. Biomark. Prev. 2012, 21, 1848-1855. [CrossRef]

6. Colzani, E.; Johansson, A.L.V.; Liljegren, A.; Foukakis, T.; Clements, M.O.; Adolfsson, J.; Hall, P.A.; Czene, K. Time-dependent risk of developing distant metastasis in breast cancer patients according to treatment, age and tumour characteristics. Br. J. Cancer 2014, 110, 1378-1384. [CrossRef] [PubMed]

7. Turner, N.C.; Neven, P.; Loibl, S.; Andre, F. Advances in the treatment of advanced oestrogen-receptor-positive breast cancer. Lancet 2017, 389, 2403-2414. [CrossRef]

8. Soni, D.A.; Ren, Z.; Hameed, O.; Chanda, D.; Morgan, C.J.; Siegal, G.P.; Wei, S. Breast Cancer Subtypes Predispose the Site of Distant Metastases. Am. J. Clin. Pathol. 2015, 143, 471-478. [CrossRef] [PubMed]

9. Hilton, J.F.; Amir, E.; Hopkins, S.; Nabavi, M.; DiPrimio, G.; Sheikh, A.; Done, S.J.; Gianfelice, D.; Kanji, F.; Dent, S.; et al. Acquisition of metastatic tissue from patients with bone metastases from breast cancer. Breast Cancer Res. Treat. 2010, 129, 761-765. [CrossRef] [PubMed]

10. Kamby, C.; Rasmussen, B.B.; Kristensen, B.W. Oestrogen receptor status of primary breast carcinomas and their metastases. Relation to pattern of spread and survival after recurrence. Br. J. Cancer 1989, 60, 252-257. [CrossRef] [PubMed]

11. Aurilio, G.; Monfardini, L.; Rizzo, S.; Sciandivasci, A.; Preda, L.; Bagnardi, V.; Disalvatore, D.; Pruneri, G.; Munzone, E.; Della Vigna, P.; et al. Discordant hormone receptor and human epidermal growth factor receptor 2 status in bone metastases compared to primary breast cancer. Acta Oncol. 2013, 52, 1649-1656. [CrossRef] [PubMed]

12. Cheng, J.N.; Frye, J.B.; Whitman, S.A.; Kunihiro, A.G.; Brickey, J.A.; Funk, J.L. Osteolytic effects of tumoral estrogen signaling in an estrogen receptor-positive breast cancer bone metastasis model. J. Cancer Metastasis Treat. 2021, 7, 17. [CrossRef]

13. Guise, T.A. Parathyroid hormone-related protein and bone metastases. Cancer 1997, 80, 1572-1580. [CrossRef]

14. Fantozzi, A.; Christofori, G. Mouse models of breast cancer metastasis. Breast Cancer Res. 2006, 8, 212. [CrossRef]

15. Wright, L.E.; Ottewell, P.D.; Rucci, N.; Peyruchaud, O.; Pagnotti, G.M.; Chiechi, A.; Buijs, J.T.; Sterling, J.A. Murine models of breast cancer bone metastasis. BoneKEy Rep. 2016, 5, 804. [CrossRef]

16. Guise, T.A. Molecular mechanisms of osteolytic bone metastases. Cancer 2000, 88, 2892-2898. [CrossRef]

17. Powell, G.J.; Southby, J.; Danks, J.A.; Stillwell, R.G.; Hayman, J.A.; Henderson, M.A.; Bennett, R.C.; Martin, T.J. Localization of parathyroid hormone-related protein in breast cancer metastases: Increased incidence in bone compared with other sites. Cancer Res. 1991, 51, 3059-3061. [PubMed]

18. Southby, J.; Kissin, M.W.; Danks, J.A.; Hayman, J.A.; Moseley, J.M.; Henderson, M.A.; Bennett, R.C.; Martin, T.J. Immunohistochemical localization of parathyroid hormone-related protein in human breast cancer. Cancer Res. 1990, 50, 7710-7716.

19. Kang, Y.; Siegel, P.M.; Shu, W.; Drobnjak, M.; Kakonen, S.M.; Cordón-Cardo, C.; Guise, T.A.; Massagué, J. A multigenic program mediating breast cancer metastasis to bone. Cancer Cell 2003, 3, 537-549. [CrossRef]

20. Sasaki, A.; Boyce, B.F.; Story, B.; Wright, K.R.; Chapman, M.; Boyce, R.; Mundy, G.R.; Yoneda, T. Bisphosphonate risedronate reduces metastatic human breast cancer burden in bone in nude mice. Cancer Res. 1995, 55, 3551-3557.

21. Buijs, J.T.; Stayrook, K.R.; Guise, T.A. The role of TGF- $\beta$ in bone metastasis: Novel therapeutic perspectives. BoneKEy Rep. 2012, 1, 96. [CrossRef]

22. Yin, J.J.; Selander, K.; Chirgwin, J.M.; Dallas, M.; Grubbs, B.G.; Wieser, R.; Massagué, J.; Mundy, G.R.; Guise, T.A. TGF- $\beta$ signaling blockade inhibits PTHrP secretion by breast cancer cells and bone metastases development. J. Clin. Investig. 1999, 103, 197-206. [CrossRef]

23. Chiechi, A.; Waning, D.L.; Stayrook, K.R.; Buijs, J.T.; Guise, T.A.; Mohammad, K.S. Role of TGF- $\beta$ in breast cancer bone metastases. Adv. Biosci. Biotechnol. 2013, 4, 15-30. [CrossRef] [PubMed]

24. Käkönen, S.-M.; Selander, K.S.; Chirgwin, J.M.; Yin, J.J.; Burns, S.; Rankin, W.A.; Grubbs, B.G.; Dallas, M.; Cui, Y.; Guise, T.A. Transforming Growth Factor- $\beta$ Stimulates Parathyroid Hormone-related Protein and Osteolytic Metastases via Smad and Mitogen-activated Protein Kinase Signaling Pathways. J. Biol. Chem. 2002, 277, 24571-24578. [CrossRef]

25. Lindemann, R.K.; Ballschmieter, P.; Nordheim, A.; Dittmer, J. Transforming Growth Factor $\beta$ Regulates Parathyroid Hormonerelated Protein Expression in MDA-MB-231 Breast Cancer Cells through a Novel Smad/Ets Synergism. J. Biol. Chem. 2001, 276, 46661-46670. [CrossRef] [PubMed]

26. Mourskaia, A.A.; Dong, Z.; Ng, S.; Banville, M.; Zwaagstra, J.C.; O'Connor-McCourt, M.D.; Siegel, P.M. Transforming growth factor- $\beta 1$ is the predominant isoform required for breast cancer cell outgrowth in bone. Oncogene 2008, 28, 1005-1015. [CrossRef] [PubMed] 
27. Deckers, M.; Van Dinther, M.; Buijs, J.; Que, I.; Löwik, C.; Van Der Pluijm, G.; Dijke, P.T. The Tumor Suppressor Smad4 Is Required for Transforming Growth Factor $\beta$-Induced Epithelial to Mesenchymal Transition and Bone Metastasis of Breast Cancer Cells. Cancer Res. 2006, 66, 2202-2209. [CrossRef] [PubMed]

28. Korpal, M.; Yan, J.; Lü, X.; Xu, S.; Lerit, D.A.; Kang, Y. Imaging transforming growth factor- $\beta$ signaling dynamics and therapeutic response in breast cancer bone metastasis. Nat. Med. 2009, 15, 960-966. [CrossRef]

29. Meng, X.; Ark, A.V.; Lee, P.; Hostetter, G.; A Bhowmick, N.; Matrisian, L.M.; O Williams, B.; Miranti, C.K.; Li, X. Myeloid-specific TGF- $\beta$ signaling in bone promotes basic-FGF and breast cancer bone metastasis. Oncogene 2016, 35, 2370-2378. [CrossRef]

30. Buenrostro, D.; Kwakwa, K.A.; Putnam, N.E.; Merkel, A.R.; Johnson, J.R.; Cassat, J.E.; Sterling, J.A. Early TGF- $\beta$ inhibition in mice reduces the incidence of breast cancer induced bone disease in a myeloid dependent manner. Bone 2018, 113, 77-88. [CrossRef]

31. Ganapathy, V.; Ge, R.; Grazioli, A.; Xie, W.; Banach-Petrosky, W.; Kang, Y.; Lonning, S.; McPherson, J.; Yingling, J.M.; Biswas, S.; et al. Targeting the Transforming Growth Factor- $\beta$ pathway inhibits human basal-like breast cancer metastasis. Mol. Cancer 2010, 9, 122. [CrossRef] [PubMed]

32. Biswas, S.; Nyman, J.S.; Alvarez, J.; Chakrabarti, A.; Ayres, A.; Sterling, J.; Edwards, J.; Rana, T.; Johnson, R.; Perrien, D.S.; et al Anti-Transforming Growth Factor $§$ Antibody Treatment Rescues Bone Loss and Prevents Breast Cancer Metastasis to Bone. PLoS ONE 2011, 6, e27090. [CrossRef] [PubMed]

33. Akhurst, R.J. Targeting TGF- $\beta$ Signaling for Therapeutic Gain. Cold Spring Harb. Perspect. Biol. 2017, 9, a022301. [CrossRef]

34. Jakowlew, S.B.; Moody, T.W.; Mariano, J.M. Transforming growth factor-beta receptors in human cancer cell lines: Analysis of transcript, protein and proliferation. Anticancer Res. 1997, 17, 1849-1860. [PubMed]

35. Kalkhoven, E.; Roelen, B.A.; De Winter, J.P.; Mummery, C.L.; Raaij, A.J.V.D.E.-V.; Van Der Saag, P.T.; Van Der Burg, B. Resistance to transforming growth factor beta and activin due to reduced receptor expression in human breast tumor cell lines. Cell Growth Differ. Mol. Boil. J. Am. Assoc. Cancer Res. 1995, 6, 1151-1161.

36. Ganapathy, V.; Banach-Petrosky, W.; Xie, W.; Kareddula, A.; Nienhuis, H.; Miles, G.; Reiss, M. Luminal breast cancer metastasis is dependent on estrogen signaling. Clin. Exp. Metastasis 2012, 29, 493-509. [CrossRef]

37. Ito, I.; Hanyu, A.; Wayama, M.; Goto, N.; Katsuno, Y.; Kawasaki, S.; Nakajima, Y.; Kajiro, M.; Komatsu, Y.; Fujimura, A.; et al. Estrogen Inhibits Transforming Growth Factor $\beta$ Signaling by Promoting Smad2/3 Degradation. J. Biol. Chem. 2010, 285, 14747-14755. [CrossRef]

38. Matsuda, T.; Yamamoto, T.; Muraguchi, A.; Saatcioglu, F. Cross-talk between Transforming Growth Factor- $\beta$ and Estrogen Receptor Signaling through Smad3. J. Biol. Chem. 2001, 276, 42908-42914. [CrossRef]

39. Stope, M.B.; Popp, S.L.; Knabbe, C.; Buck, M.B. Estrogen receptor $\alpha$ attenuates transforming growth factor- $\beta$ signaling in breast cancer cells independent from agonistic and antagonistic ligands. Breast Cancer Res. Treat. 2009, 120, 357-367. [CrossRef]

40. Kleuser, B.; Malek, D.; Gust, R.; Pertz, H.H.; Potteck, H. 17- $\beta$-Estradiol Inhibits Transforming Growth Factor- $\beta$ Signaling and Function in Breast Cancer Cells via Activation of Extracellular Signal-Regulated Kinase through the G Protein-Coupled Receptor 30. Mol. Pharmacol. 2008, 74, 1533-1543. [CrossRef] [PubMed]

41. Wright, L.E.; Frye, J.B.; Lukefahr, A.L.; Timmermann, B.N.; Mohammad, K.S.; Guise, T.A.; Funk, J.L. Curcuminoids Block TGF- $\beta$ Signaling in Human Breast Cancer Cells and Limit Osteolysis in a Murine Model of Breast Cancer Bone Metastasis. J. Nat. Prod. 2012, 76, 316-321. [CrossRef]

42. Siersbæk, R.; Kumar, S.; Carroll, J.S. Signaling pathways and steroid receptors modulating estrogen receptor $\alpha$ function in breast cancer. Genes Dev. 2018, 32, 1141-1154. [CrossRef]

43. Kunihiro, A.G.; Brickey, J.A.; Frye, J.B.; Luis, P.B.; Schneider, C.; Funk, J.L. Curcumin, but not curcumin-glucuronide, inhibits Smad signaling in TGF $\beta$-dependent bone metastatic breast cancer cells and is enriched in bone compared to other tissues. J. Nutr. Biochem. 2019, 63, 150-156. [CrossRef] [PubMed]

44. Zhang, Y.E. Non-Smad Signaling Pathways of the TGF- $\beta$ Family. Cold Spring Harb. Perspect. Biol. 2016, 9, a022129. [CrossRef] [PubMed]

45. Yu, J.; Henske, E.P. Estrogen-Induced Activation of Mammalian Target of Rapamycin Is Mediated via Tuberin and the Small GTPase Ras Homologue Enriched in Brain. Cancer Res. 2006, 66, 9461-9466. [CrossRef] [PubMed]

46. Cuesta, R.; Gritsenko, M.A.; Petyuk, V.A.; Shukla, A.K.; Tsai, C.-F.; Liu, T.; McDermott, J.E.; Holz, M.K. Phosphoproteome Analysis Reveals Estrogen-ER Pathway as a Modulator of mTOR Activity Via DEPTOR. Mol. Cell. Proteom. 2019, 18, 1607-1618. [CrossRef]

47. Gil, E.M.C. Targeting the PI3K/AKT/mTOR pathway in estrogen receptor-positive breast cancer. Cancer Treat. Rev. 2014, 40, 862-871. [CrossRef]

48. Edwards, J.R.; Nyman, J.S.; Lwin, S.T.; Moore, M.M.; Esparza, J.; O'Quinn, E.C.; Hart, A.J.; Biswas, S.; Patil, C.A.; Lonning, S.; et al. Inhibition of TGF- $\beta$ signaling by 1D11 antibody treatment increases bone mass and quality in vivo. J. Bone Miner. Res. 2010, 25, 2419-2426. [CrossRef]

49. Cheng, J.N.; Frye, J.B.; Whitman, S.A.; Funk, J.L. Skeletal impact of $17 \beta$-estradiol in T cell-deficient mice: Age-dependent bone effects and osteosarcoma formation. Clin. Exp. Metastasis 2019, 37, 269-281. [CrossRef]

50. Sawant, A.; Deshane, J.; Jules, J.; Lee, C.M.; Harris, B.A.; Feng, X.; Ponnazhagan, S. Myeloid-Derived Suppressor Cells Function as Novel Osteoclast Progenitors Enhancing Bone Loss in Breast Cancer. Cancer Res. 2013, 73, 672-682. [CrossRef]

51. Zhuang, J.; Zhang, J.; Lwin, S.T.; Edwards, J.R.; Edwards, C.M.; Mundy, G.R.; Yang, X. Osteoclasts in Multiple Myeloma Are Derived from Gr-1+CD11b+Myeloid-Derived Suppressor Cells. PLoS ONE 2012, 7, e48871. [CrossRef] [PubMed] 
52. Danilin, S.; Merkel, A.R.; Johnson, J.R.; Johnson, R.W.; Edwards, J.R.; Sterling, J.A. Myeloid-derived suppressor cells expand during breast cancer progression and promote tumor-induced bone destruction. OncoImmunology 2012, 1, 1484-1494. [CrossRef] [PubMed]

53. Pang, Y.; Gara, S.K.; Achyut, B.R.; Li, Z.; Yan, H.H.; Day, C.-P.; Weiss, J.M.; Trinchieri, G.; Morris, J.C.; Yang, L. TGF- $\beta$ Signaling in Myeloid Cells Is Required for Tumor Metastasis. Cancer Discov. 2013, 3, 936-951. [CrossRef]

54. Hering, S.; Isken, F.; Knabbe, C.; Janott, J.; Jost, C.; Pommer, A.; Muhr, G.; Schatz, H.; Pfeiffer, A.F. TGF $\beta 1$ and TGF $\beta 2$ mRNA and protein expression in human bone samples. Exp. Clin. Endocrinol. Diabetes 2001, 109, 217-226. [CrossRef] [PubMed]

55. Seyedin, S.M.; Thomas, T.C.; Thompson, A.Y.; Rosen, D.M.; Piez, K.A. Purification and characterization of two cartilage-inducing factors from bovine demineralized bone. Proc. Natl. Acad. Sci. USA 1985, 82, 2267-2271. [CrossRef]

56. Chen, Y.-C.; Sosnoski, D.M.; Mastro, A.M. Breast cancer metastasis to the bone: Mechanisms of bone loss. Breast Cancer Res. 2010, 12, 215. [CrossRef]

57. Kakonen, S.M.; Selander, K.S.; Carreon, M.R.; Cui, Y.; Neal, M.; Chirgwin, J.M.; Grubbs, B.G.; Guise, T.A. TGF $\beta$ signaling in osteolytic cancer cell lines: Stimulation of IL-6, IL-11, PTHrP, and VEGF through MAP kinase pathways. J. Bone Miner. Res. 2001, $69,313$.

58. Petersen, M.; Pardali, E.; Van Der Horst, G.; Cheung, H.; Hoogen, C.V.D.; Van Der Pluijm, G.; Dijke, P.T. Smad2 and Smad3 have opposing roles in breast cancer bone metastasis by differentially affecting tumor angiogenesis. Oncogene 2009, 29, 1351-1361. [CrossRef]

59. Fachal, L.; GEMO Study Collaborators; Aschard, H.; Beesley, J.; Barnes, D.R.; Allen, J.; Kar, S.; Pooley, K.A.; Dennis, J.; Michailidou, K.; et al. Fine-mapping of 150 breast cancer risk regions identifies 191 likely target genes. Nat. Genet. 2020, 52, 56-73. [CrossRef]

60. Kang, Y.; He, W.; Tulley, S.; Gupta, G.P.; Serganova, I.; Chen, C.-R.; Manova-Todorova, K.; Blasberg, R.; Gerald, W.L.; Massagué, J. Breast cancer bone metastasis mediated by the Smad tumor suppressor pathway. Proc. Natl. Acad. Sci. USA 2005, 102, 13909-13914. [CrossRef]

61. Holen, I.; Walker, M.; Nutter, F.; Fowles, A.; Evans, C.A.; Eaton, C.L.; Ottewell, P.D. Oestrogen receptor positive breast cancer metastasis to bone: Inhibition by targeting the bone microenvironment in vivo. Clin. Exp. Metastasis 2015, 33, 211-224. [CrossRef]

62. Yin, J.J.; Mohammad, K.S.; Käkönen, S.M.; Harris, S.; Wu-Wong, J.R.; Wessale, J.L.; Padley, R.J.; Garrett, I.R.; Chirgwin, J.M.; Guise, T.A. A causal role for endothelin-1 in the pathogenesis of osteoblastic bone metastases. Proc. Natl. Acad. Sci. USA 2003, 100, 10954-10959. [CrossRef]

63. Zhao, H.; Zhou, L.; Shangguan, A.J.; Bulun, S.E. Aromatase expression and regulation in breast and endometrial cancer. J. Mol. Endocrinol. 2016, 57, R19-R33. [CrossRef] [PubMed]

64. Sjögren, K.; Lagerquist, M.; Moverare-Skrtic, S.; Andersson, N.; Windahl, S.H.; Swanson, C.; Mohan, S.; Poutanen, M.; Ohlsson, C. Elevated Aromatase Expression in Osteoblasts Leads to Increased Bone Mass Without Systemic Adverse Effects. J. Bone Miner. Res. 2009, 24, 1263-1270. [CrossRef] [PubMed]

65. Shozu, M.; Zhao, Y.; Simpson, E.R. TGF- $\beta 1$ stimulates expression of the aromatase (CYP19) gene in human osteoblast-like cells and THP-1 cells. Mol. Cell. Endocrinol. 2000, 160, 123-133. [CrossRef]

66. Baselga, J.; Campone, M.; Piccart-Gebhart, M.; Burris, H.A.; Rugo, H.S.; Sahmoud, T.; Noguchi, S.; Gnant, M.; Pritchard, K.I.; Lebrun, F; et al. Everolimus in Postmenopausal Hormone-Receptor-Positive Advanced Breast Cancer. N. Engl. J. Med. 2012, 366, 520-529. [CrossRef]

67. Murayama, T.; Gotoh, N. Patient-Derived Xenograft Models of Breast Cancer and Their Application. Cells 2019, 8, 621. [CrossRef]

68. Dobrolecki, L.E.; Airhart, S.D.; Alferez, D.G.; Aparicio, S.; Behbod, F.; Bentires-Alj, M.; Brisken, C.; Bult, C.J.; Cai, S.; Clarke, R.B.; et al. Patient-derived xenograft (PDX) models in basic and translational breast cancer research. Cancer Metastasis Rev. 2016, 35, 547-573. [CrossRef] [PubMed]

69. Matthews, S.B.; Sartorius, C.A. Steroid Hormone Receptor Positive Breast Cancer Patient-Derived Xenografts. Horm. Cancer 2017, 8, 4-15. [CrossRef]

70. Osborne, C.K.; Hobbs, K.; Clark, G.M. Effect of estrogens and antiestrogens on growth of human breast cancer cells in athymic nude mice. Cancer Res. 1985, 45, 584-590. [PubMed]

71. Ogba, N.; Manning, N.G.; Bliesner, B.S.; Ambler, S.K.; Haughian, J.M.; Pinto, M.P.; Jedlicka, P.; Joensuu, K.; Heikkilä, P.; Horwitz K.B. Luminal breast cancer metastases and tumor arousal from dormancy are promoted by direct actions of estradiol and progesterone on the malignant cells. Breast Cancer Res. 2014, 16, 489. [CrossRef] [PubMed]

72. Sowder, M.E.; Johnson, R.W. Enrichment and detection of bone disseminated tumor cells in models of low tumor burden. Sci. Rep. 2018, 8, 14299. [CrossRef] [PubMed]

73. Canon, J.; Bryant, R.; Roudier, M.; Branstetter, D.G.; Dougall, W.C. RANKL inhibition combined with tamoxifen treatment increases anti-tumor efficacy and prevents tumor-induced bone destruction in an estrogen receptor-positive breast cancer bone metastasis model. Breast Cancer Res. Treat. 2012, 135, 771-780. [CrossRef]

74. Fisher, J.L.; Thomas-Mudge, R.J.; Elliott, J.; Hards, D.K.; Sims, N.A.; Slavin, J.; Martin, T.J.; Gillespie, M.T. Osteoprotegerin Overexpression by Breast Cancer Cells Enhances Orthotopic and Osseous Tumor Growth and Contrasts with That Delivered Therapeutically. Cancer Res. 2006, 66, 3620-3628. [CrossRef] [PubMed]

75. Gawrzak, S.; Rinaldi, L.; Gregorio, S.; Arenas, E.J.; Salvador, F.; Urosevic, J.; Figueras-Puig, C.; Rojo, F.; Barrantes, I.D.B.; Cejalvo, J.M.; et al. MSK1 regulates luminal cell differentiation and metastatic dormancy in ER+ breast cancer. Nat. Cell Biol. 2018, 20, 211-221. [CrossRef] [PubMed] 
76. Johnson, R.W.; Finger, E.C.; Olcina, M.M.; Vilalta, M.; Aguilera, T.; Miao, Y.; Merkel, A.R.; Johnson, J.R.; Sterling, J.A.; Wu, J.Y.; et al. Induction of LIFR confers a dormancy phenotype in breast cancer cells disseminated to the bone marrow. Nat. Cell Biol. 2016, 18, 1078-1089. [CrossRef]

77. Pavlovic, M.; Arnal-Estapé, A.; Rojo, F.; Bellmunt, A.; Tarragona, M.; Guiu, M.; Planet, E.; Garcia-Albéniz, X.; Morales, M.; Urosevic, J.; et al. Enhanced MAF Oncogene Expression and Breast Cancer Bone Metastasis. J. Natl. Cancer Inst. 2015, 107, djv256. [CrossRef]

78. Thomas, R.J.; Guise, T.A.; Yin, J.J.; Elliott, J.; Horwood, N.J.; Martin, T.J.; Gillespie, M.T. Breast Cancer Cells Interact with Osteoblasts to Support Osteoclast Formation1. Endocrinology 1999, 140, 4451-4458. [CrossRef]

79. Ottewell, P.D.; Wang, N.; Brown, H.K.; Reeves, K.J.; Fowles, C.A.; Croucher, P.I.; Eaton, C.L.; Holen, I. Zoledronic Acid Has Differential Antitumor Activity in the Pre- and Postmenopausal Bone Microenvironment In Vivo. Clin. Cancer Res. 2014, 20, 2922-2932. [CrossRef]

80. Reinert, T.; Barrios, C.H. Optimal management of hormone receptor positive metastatic breast cancer in 2016. Ther. Adv. Med Oncol. 2015, 7, 304-320. [CrossRef]

81. Abe, O.; Abe, R.; Enomoto, K.; Kikuchi, K.; Koyama, H.; Masuda, H.; Nomura, Y.; Sakai, K.; Sugimachi, K.; Tominaga, T.; et al. Effects of chemotherapy and hormonal therapy for early breast cancer on recurrence and 15-year survival: An overview of the randomised trials. Lancet 2005, 365, 1687-1717. [CrossRef]

82. Guise, T.A.; Yin, J.J.; Taylor, S.D.; Kumagai, Y.; Dallas, M.; Boyce, B.F.; Yoneda, T.; Mundy, G.R. Evidence for a causal role of parathyroid hormone-related protein in the pathogenesis of human breast cancer-mediated osteolysis. J. Clin. Investig. 1996, 98, 1544-1549. [CrossRef] [PubMed]

83. Noh, W.-C.; Mondesire, W.H.; Peng, J.; Jinjiang, D.; Zhang, H.; Dong, J.; Mills, G.B.; Hung, M.-C.; Meric-Bernstam, F. Determinants of Rapamycin Sensitivity in Breast Cancer Cells. Clin. Cancer Res. 2004, 10, 1013-1023. [CrossRef] [PubMed]

84. Mourskaia, A.A.; Amir, E.; Dong, Z.; Tiedemann, K.; Cory, S.; Omeroglu, A.; Bertos, N.; Ouellet, V.; Clemons, M.; Scheffer, G.L.; et al. ABCC5 supports osteoclast formation and promotes breast cancer metastasis to bone. Breast Cancer Res. 2012, 14, R149. [CrossRef] [PubMed]

85. Ritchie, M.E.; Phipson, B.; Wu, D.; Hu, Y.; Law, C.W.; Shi, W.; Smyth, G.K. limma powers differential expression analyses for RNA-sequencing and microarray studies. Nucleic Acids Res. 2015, 43, e47. [CrossRef]

86. Dempster, D.W.; Compston, J.E.; Drezner, M.K.; Glorieux, F.H.; Kanis, J.A.; Malluche, H.; Meunier, P.J.; Ott, S.M.; Recker, R.R.; Parfitt, A.M. Standardized nomenclature, symbols, and units for bone histomorphometry: A 2012 update of the report of the ASBMR Histomorphometry Nomenclature Committee. J. Bone Miner. Res. 2012, 28, 2-17. [CrossRef] [PubMed] 